UNIVERSIDADE DE SÃO PAULO

CENTRO DE ENERGIA NUCELAR NA AGRICULTURA

LUCIANA MARCHESE

Sorção/dessorção e lixiviação do herbicida ametrina em solos canavieiros tratados com lodo de esgoto 


\section{Sorção/dessorção e lixiviação do herbicida ametrina em solos canavieiros tratados com lodo de esgoto}

Dissertação apresentada ao Centro de Energia Nuclear na Agricultura da Universidade de São Paulo para obtenção do título de Mestre em Ciências.

Área de Concentração: Química na Agricultura e no Ambiente

Orientadora: Profa. Dra. Jussara Borges Regitano 


\section{AUTORIZO A REPRODUÇÃO E DIVULGAÇÃO TOTAL OU PARCIAL DESTE TRABALHO, POR QUALQUER MEIO CONVENCIONAL OU ELETRÔNICO, PARA FINS DE ESTUDO E PESQUISA, DESDE QUE CITADA A FONTE.}

Dados Internacionais de Catalogação na Publicação (CIP)

\section{Seção Técnica de Biblioteca - CENA/USP}

Marchese, Luciana

Sorção/desorção e lixiviação do herbicida ametrina em solos canavieiros tratados com lodo de esgoto / Luciana Marchese; orientadora Jussara Borges Regitano. - - Piracicaba, 2007.

$81 \mathrm{f}$. : fig.

Dissertação (Mestrado - Programa de Pós-Graduação em Ciências. Área de Concentração: Química na Agricultura e no Ambiente) - Centro de Energia Nuclear na Agricultura da Universidade de São Paulo.

1. Águas subterrâneas 2. Biossólidos 3. Disposição no solo de lodo 4. Matéria orgânica do solo 5. Triazina I. Título 


\section{DEDICATÓRIA}

A meus pais e irmãos, com amor e gratidão por sua presença e apoio durante toda a minha vida.

A meu esposo, Joilson, com admiração e gratidão pela paciência e incentivo incansavelmente a mim dispensados ao longo do período de elaboração deste trabalho e por acreditar mais em mim do que eu mesma.

A meu filho, João Pedro, pela paciência e compreensão nos momentos de ausência durante a condução deste trabalho. 


\section{AGRADECIMENTOS}

Primeiramente à Deus, pelos oportunidades de aprendizagem ao longo da vida.

À professora Dra. Jussara Borges Regitano, pela orientação, pelos ensinamentos fundamentais à execução deste trabalho e acima de tudo, pela amizade e respeito dedicados a mim em todos os momentos que precisei.

Ao professor Dr. Valdemar Luiz Tornisielo, pelos ensinamentos, apoio e incentivo nos últimos anos.

À amiga Rosângela Aparecida De Gaspari Rocha, pelo apoio técnico na condução dos experimentos e principalmente, pelo amizade e alegria compartilhadas nos últimos sete anos.

Ao colega e técnico Carlos Aberto Dorelli, pela experiência profissional compartilhada e amizade.

Ao Prof. Dr. Pablo Vidal Torrado pela atenção dispensada com relação aos solos utilizados.

À Prof. Dra. Sônia M. De S. Piedade pela orientação nas análises estatísticas.

Ao Prof. Dr. Fernando Carvalho Oliveira pelos ensinamentos compartilhados sobre os lodos de esgoto utilizados e pela disponibilização do lodo de esgoto proveniente da Companhia de Saneamento de Jundiaí.

À professora Dra. Marisa de C. Piccolo e à técnica Lilian A. de Campos pelas análises de apoio realizadas.

Ao Sr. Rui C. Bueno, da Companhia de Saneamento Básico do Estado de São Paulo - Franca e Sr. Carlos R. Ferreira, da Ambient Ribeirão Preto S.A., pelo fornecimento dos lodos utilizados e informações correspondentes.

Ao Sérgio Luis de Jesus, do NUPEGEL, pela atenção dispensada.

À secretaria de pós-graduação do Centro de Energia Nuclear na Agricultura (CENA) pelo atendimento cordial.

À bibliotecária Marilia R. G. Henyei pelas correções e atendimento cordial.

Aos colegas de trabalho da Dow AgroSicences, Ana, Flávia, Geisa, Heloisa, Martha, Otávio, Paulo, Roberto e Ruy, pela compreensão, paciência e apoio durante a condução deste trabalho.

Aos alunos e colegas do Laboratório de Ecotoxicologia (CENA), Ana Cláudia, Cidinha, Guilherme e Neide pelo agradável convívio e amizade e, especialmente à Giuliane, pelos finais de semana e feriados dedicados ao meu trabalho. 
Às amigas Alisângela, Cláudia, Elaine, Juliana, Lucy, Michele e Tatiana, pelo carinho e eterna amizade.

Aos meus familiares, pelo apoio, incentivo e confiança sempre a mim dispensados.

À CNPq pela concessão de bolsa de mestrado no início do trabalho.

À FAPESP pela concessão de bolsa de mestrado e apoio financeiro.

A todos aqueles que por ventura tenha me esquecido, mas que contribuíram com este trabalho. 
"Há homens que lutam um dia e são bons.

Há outros que lutam um ano e são melhores.

Há os que lutam muitos anos e são muito bons.

Porém, há os que lutam toda a vida.

Esses são os imprescindíveis."

(Bertolt Brecht) 


\section{Resumo}

Vários estudos têm mostrado os benefícios da aplicação agronômica de lodo de esgoto sobre as propriedades físicas e químicas do solo. No entanto, poucos são aqueles que avaliam o impacto desta prática sobre o comportamento de pesticidas em solos tropicais. O principal objetivo deste estudo foi avaliar o efeito da adição de diferentes fontes de lodo (Ribeirão Preto, Franca e Jundiaí) na sorção / dessorção e lixiviação do herbicida ametrina em solos canavieiros do estado de São Paulo (Neossolo Quartzarênico Órtico Típico (RQ), Latossolo Vermelho Distrófico Típico (LVd), Argissolo Vermelho Eutroférrico Chernossólico (PV) e Latossolo Vermelho Distroférrico (LVdf). Cinco concentrações (de 4,4 a 79,8 mg i.a. $\mathrm{L}^{-1}$ ) do herbicida foram utilizadas para obter os valores dos coeficientes de sorção de Freündlich $\left(\mathrm{K}_{\mathrm{f}}\right)$ e dos coeficientes aparentes de sorção médio e para a menor concentração $\left(\mathrm{K}_{\mathrm{d}}{ }^{\mathrm{ap}}{ }_{\text {médio }} \mathrm{e}\right.$ $\mathrm{K}_{\mathrm{d}}^{\mathrm{ap}}{ }_{[\mathrm{menor}]}$ ), a qual corresponde à dose de campo recomendada. Para o teste de lixiviação, o método utilizado foi o de lixiviação em colunas de solo (diâmetro $=5 \mathrm{~cm}$ e comprimento $=30$ $\mathrm{cm}$ ), utilizando-se três repetições para cada tratamento, sobre as quais foi simulada chuva de $200 \mathrm{~mm}$ uniformemente distribuídas durante $48 \mathrm{~h}$, após a aplicação da solução de ${ }^{14} \mathrm{C}$ ametrina na dose de 3,0 kg i.a. ha ${ }^{-1}$. De forma geral, a sorção da ametrina variou de moderada à alta em todos os tratamentos $\left(2,68<\mathrm{K}_{\mathrm{d}}{ }^{\mathrm{ap}}{ }_{[\text {menor }]}<85,71 \mathrm{~L} \mathrm{~kg}^{-1}\right)$. Solos argilosos com maior teor de matéria orgânica e argilas do tipo 2:1, como é o caso do PV, apresentaram muito maior potencial de sorção da ametrina; enquanto que solos arenosos com baixos teores de matéria orgânica, como foram os casos do LVd e RQ, apresentaram moderado potencial de sorção. A aplicação de lodos menos estabilizados, com biomassa e material orgânico menos recalcitrante e, portanto, com maiores valores de carbono orgânico total, carbono orgânico dissolvido e pH, como é o caso do lodo de Ribeirão Preto, tendeu a diminuir o potencial de sorção da ametrina. Já a adição de lodos mais recalcitrantes, como o de Jundiaí, tendeu a 
aumentar o potencial de sorção da ametrina, principalmente em solos arenosos devido a sua menor capacidade tampão. Nestes cenários, poderá ocorrer redução da eficácia agronômica ametrina, uma vez que haverá menos produto disponível na solução do solo. A ametrina apresentou baixo potencial de lixiviação $(<1 \%$ da quantidade aplicada) em todos os tratamentos, os quais não apresentaram diferenças entre si, sendo que a grande maioria do pesticida ( $>95 \%$ da quantidade aplicada) ficou retida na camada de $0-10 \mathrm{~cm}$ de profundidade da coluna de solo. Isto implica dizer que a ametrina apresenta baixo potencial de contaminar águas subterrâneas, mesmo em solos arenosos, como RQ (90\% de areia).

Palavras-chave: retenção, triazina, resíduo orgânico, carbono orgânico dissolvido, percolação, águas subterrâneas 


\section{Abstract}

Several studies have shown the benefits of applying sewage sludge on the physical and chemical properties of the soils. However, just a few of them evaluates the impact of this practice on the behavior of pesticides in tropical soils. The main goal of this research was to evaluate the effects of applying different sources of sewage sludge (Ribeirão Preto, Franca e Jundiaí) on the sorption / desorption and leaching of ametryne in soils from São Paulo state (Brazil) cultivated with sugarcane (Neossolo Quartzarênico Órtico Típico (RQ), Latossolo Vermelho Distrófico Típico (LVd), Argissolo Vermelho Eutroférrico Chernossólico (PV) e Latossolo Vermelho Distroférrico (LVdf). Five concentrations (4.4 to $79.8 \mathrm{mg}$ a.i. $\mathrm{ha}^{-1}$ ) of the herbicide were applied to the soil samples to attain the Freündlich sorption coefficients $\left(\mathrm{K}_{\mathrm{f}}\right)$ and the apparent sorption coefficient for the lower concentration $\left(\mathrm{K}_{\mathrm{d}}{ }_{[\mathrm{menor}]}^{\mathrm{ap}}\right)$, which corresponded to the field application rate. For the leaching test the adopted method was the soil leaching columns $($ diameter $=5 \mathrm{~cm}$ and depth $=30 \mathrm{~cm})$, in triplicates, over which a 200 $\mathrm{mm}$ rainfall evenly distributed during $48 \mathrm{~h}$ was simulated just after ametryne application at the rate of $3.0 \mathrm{~kg}$ a.i. $\mathrm{ha}^{-1}$. In general, ametryne sorption ranged from moderate to high in all treatments $\left(2.68<\mathrm{K}_{\mathrm{d}}{ }_{[\text {menor] }}^{\mathrm{ap}}<85.71 \mathrm{~L} \mathrm{~kg}^{-1}\right)$. Clay soils with higher organic matter and 2:1 clay contents, such as the PV, showed much higher sorption potential, whereas sand soils with low organic matter content, such as LVd and RQ, showed moderate sorption potential. The application of less stabilized sewage sludges, with less recalcitrant biomass and organic material and, therefore, with higher organic matter and dissolved organic carbon contents and $\mathrm{pH}$ values, such as the Ribeirão Preto, tends to decrease ametryne sorption potential. Otherwise, the addition of more recalcitrant sludges, such as the Jundiaí, tends to enhance its sorption potential, mainly in sand soils due to its lower buffer capacity. In those cases, the agronomic efficacy of ametryne may be reduced since there is lower concentration of the compound available in the soil solution. The ametryne presented low leaching potential in all 
treatments $(<1 \%$ of the applied amount), which were not different among themselves, and that its majority ( $>95 \%$ of the applied amount) was found at $0-10 \mathrm{~cm}$ soil depth in the column. It implies that ametryne has low potential to contaminate groundwater even in sandy soils, such as the RQ (90\% sand).

Key words: retention, triazine, organic residues, dissolved organic carbon, percolation, ground water 


\section{SUMÁRIO}

1. INTRODUÇÃO

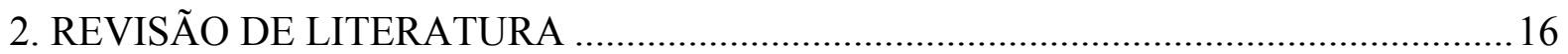

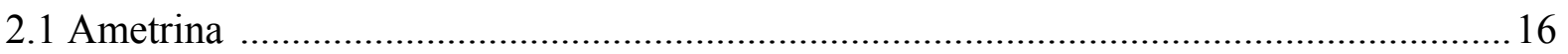

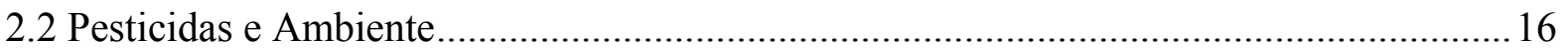

2.3 Os processos de sorção/dessorção de pesticidas..................................................................19

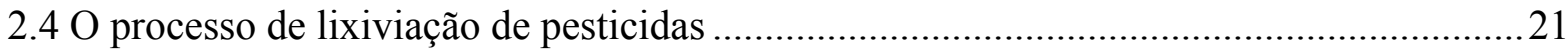

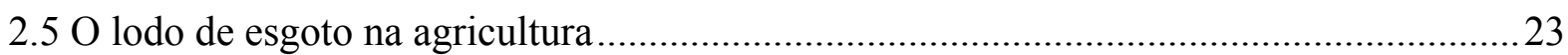

3. SORÇÃO E DESSORÇÃO DO HERBICIDA AMETRINA EM SOLOS CANAVIEIROS

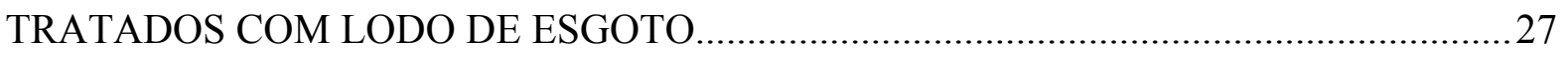

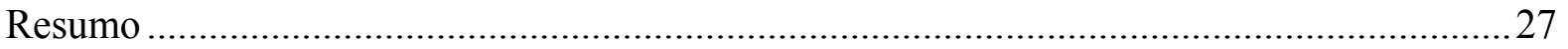

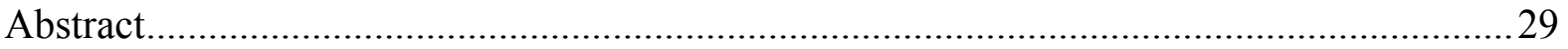

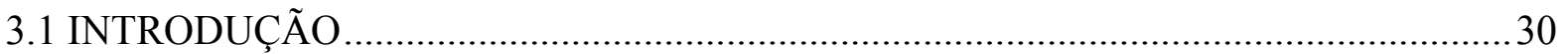

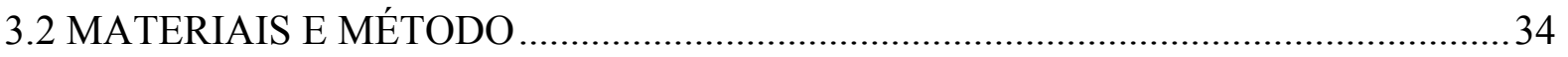

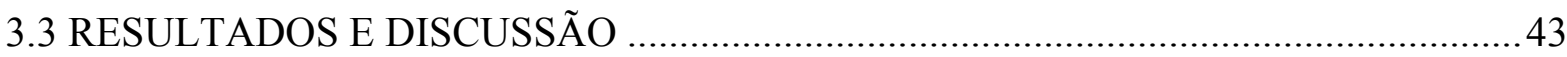

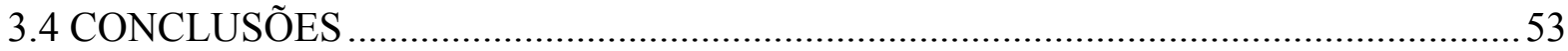

4. LIXIVIAÇÃO DO HERBICIDA AMETRINA EM SOLOS CANAVIEIROS TRATADOS

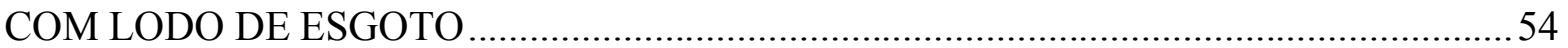

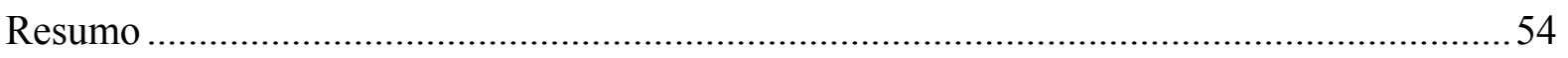

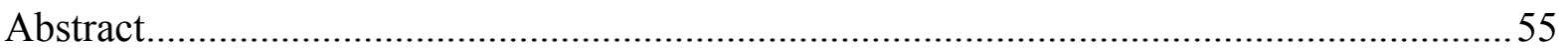

4.1 INTRODUÇÃ

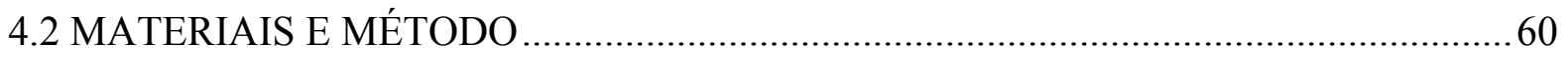

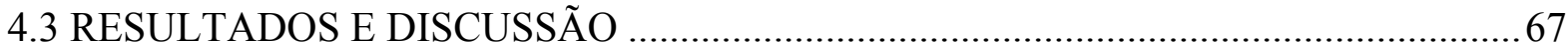

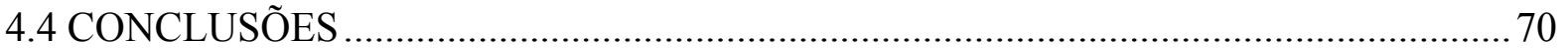

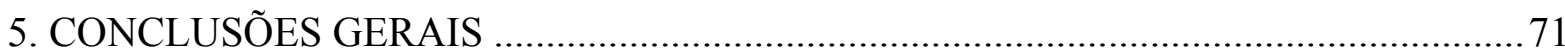

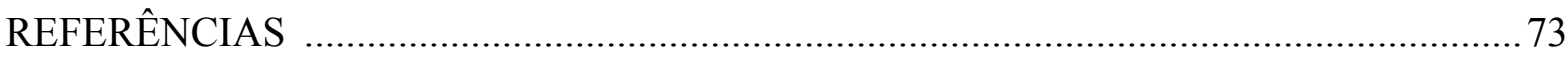




\section{INTRODUÇÃO}

O grande consumo de pesticidas na agricultura constitui hoje em realidade constatada não somente nos países desenvolvidos, mas também em praticamente todos os países do mundo. Estudos revelam que mais da metade da produção mundial de pesticidas é consumida nos Estados Unidos e na Europa Ocidental, regiões que correspondem a cerca de $25 \%$ das terras globais ocupadas com culturas. Por outro lado, cerca de $20 \%$ dos pesticidas são consumidos nos países em desenvolvimento, que contam com 55\% das terras cultivadas do mundo (ALVES FILHO, 2004).

No Brasil, na década de 60, a chamada "Revolução Verde" impulsionou a utilização de pesticidas, o que levou ao aumento na produtividade, ao mesmo tempo em que trouxe conseqüências adversas ao homem e ao meio ambiente. Segundo dados do Sindag (2004) (Sindicato Nacional da Indústria de Produtos para Defesa Agrícola), hoje o Brasil ocupa a oitava posição em relação ao consumo mundial de pesticidas, destacando-se entre eles, os herbicidas, tanto em âmbito nacional como mundial.

Nos países desenvolvidos, a contaminação ambiental causada pelo uso de pesticidas mobiliza muito a opinião pública, preocupada em preservar os recursos naturais, principalmente, as águas. Por outro lado, no Brasil, praticamente não há vigilância dos sistemas aquáticos, nem monitoramento ou tratamento de águas de consumo para detectar e/ou eliminar pesticidas (DE LUNA; DE SALES; DA SILVA, 2007).

Calcula-se que apenas cerca de $0,1 \%$ dos pesticidas utilizados atinge o alvo específico, enquanto que os $99,9 \%$ restantes da aplicação têm potencial de transferência para os diferentes compartimentos do ambiente, tais como ar, solo e águas superficiais e subterrâneas 
(BELLUCK; BENJAMIN; DAWSON, 1991; UETA et al., 2004). Chaim et al. (1999) citam que os componentes ambientais com maiores potenciais de contaminação são: as nascentes, poços, açudes, lagos, rios, fauna e flora silvestres, solos explorados ou não para cultivo, a atmosfera e o homem. O uso de pesticidas sempre gera a possibilidade de ocorrer contaminação ambiental, e muito comumente isto ocorre por acidente, descuido, negligência ou falta de conhecimento.

Para estudar a contaminação e a qualidade das águas superficiais e subsuperficiais pelo uso de pesticidas, é fundamental que se conheçam os processos que influenciam o seu comportamento no solo. Ao chegar ao solo, a molécula de um pesticida pode sofrer os processos de sorção (envolve a formação de resíduos ligados) e degradação; podendo ser absorvido pelas plantas, lixiviado às camadas subsuperficiais do solo, bem como sofrer escoamento superficial, podendo atingir respectivamente os cursos de água subterrâneos e superficiais (LAVORENTI; PRATA; REGITANO, 2003).

O processo de sorção corresponde à capacidade de retenção da molécula de pesticida à superfície do solo, sedimento ou outra matriz de interesse (CHAPLAIN, et al., 2001; Grover, 1975; REGITANO et al., 2002). Geralmente, quanto maior for a sorção de um pesticida ao solo, menor será a sua disponibilidade e a sua taxa de degradação e, consequentemente, menor a sua mobilidade, sendo menores as chances deste produto alcançar águas subsuperficiais e/ou subterrâneas.

O processo de lixiviação é considerado a principal rota de contaminação de mananciais aquáticos sub-superficiais com pesticidas. Este processo refere-se ao movimento descendente dos pesticidas em solução ao longo do perfil do solo, o qual depende das características físicoquímicas do pesticida, das características e propriedades do solo e das condições climáticas (INOUE et al., 2003). Vale lembrar, que além da contaminação de águas, a lixiviação de 
herbicidas pode reduzir a eficácia destes no controle de plantas daninhas, acarretando assim, prejuízos financeiros aos produtores (FUTCH, 1999).

Diversos trabalhos enfatizam a influência da matéria orgânica sobre a sorção e a persistência de pesticidas no solo (BARRIUSO, HOUOT, SERRA-WITTLING., 1997; REGITANO et al., 2000). A adição de qualquer tipo de material orgânico a um solo irá influenciar diretamente o comportamento ambiental de um pesticida, podendo torná-lo mais persistente devido ao incremento no potencial de sorção ao solo, ou degradá-lo mais rapidamente devido à aceleração na atividade microbiana deste mesmo solo (REGITANO et al., 2002). Portanto, maior atenção deve ser dada à incorporação ao solo de resíduos orgânicos, como por exemplo, o lodo de esgoto, uma vez que isto irá influenciar diretamente a dinâmica do pesticida no ambiente.

Atualmente, a aplicação agrícola do lodo de esgoto tem demonstrado várias vantagens, tais como aumento da porosidade total e da macroporosidade (e, consequentemente, diminuição na densidade do solo), maior retenção de água, manutenção do pH do solo (ou da capacidade tampão do solo), aumento da resistência à erosão, melhora da capacidade de troca de cátions, aumento no reservatório de nutrientes, além de estimular a atividade microbiana do solo (DE MELO et al., 2004; DOS SANTOS, 2003). Muitas são as vantagens agronômicas da aplicação do lodo de esgoto, no entanto, é de extrema importância atentar para as questões ambientais.

O Brasil é o maior produtor de cana-de-açúcar do mundo (Organização de Plantadores de Cana do Estado de São Paulo, 2007), com produção aproximada de 458 milhões de toneladas na safra de 2006 e previsão de 484 milhões de toneladas para a safra de 2007, sendo que o Estado de São Paulo é responsável por 58\% da produção nacional (Instituto Brasileiro de Geografia e Estatística, 2007). Na região de Piracicaba, São Paulo, a aplicação de lodo de esgoto vem sendo utilizada em algumas áreas produtoras de cana-de-açúcar, sendo que 
algumas dessas áreas vêm demonstrando uma redução na eficácia agronômica dos herbicidas pré-emergentes utilizados na cultura da cana-de-açúcar, provavelmente pelo aumento de seu potencial de sorção, o que resultaria na diminuição de sua disponibilidade na solução do solo.

Nesse contexto, este trabalho estudou a influência da aplicação de diferentes fontes de lodo de esgoto nos processos de sorção e lixiviação do herbicida ametrina em solos canavieiros, com diferentes teores de carbono orgânico e argila, de maneira que se possa predizer, com um maior grau de veracidade, o seu potencial de transporte. Estas informações poderão servir de auxílio no desenvolvimento de práticas de manejo que visam o aumento da eficácia do herbicida e a minimização dos riscos de contaminação ambiental. 


\section{REVISÃO DE LITERATURA}

\subsection{Ametrina}

Pertencente ao grupo das triazinas, a ametrina é um dos herbicidas mais utilizados no Brasil, sendo aplicada em pré e pós emergência no controle de plantas daninhas anuais (folhas estreitas e largas) associadas à cultura da cana-de-açúcar, dentre outras. Em contato com o solo, fica sujeita primariamente à degradação microbiana, sendo relativamente persistente $\left(\mathrm{DT}_{50}=70\right.$ a 129 dias $)$.

Trata-se de um herbicida ionizável, com caráter básico $\left(\mathrm{pK}_{\mathrm{a}}=4.1\right)$; solubilidade em água $=200 \mathrm{mg} \mathrm{L}^{-1}$ a $25{ }^{\circ} \mathrm{C}$; pressão de vapor $=3,7 \times 10^{-4} \mathrm{~Pa} ; \log \mathrm{K}_{\mathrm{ow}}=2,63$ e $\mathrm{K}_{\mathrm{oc}}=100 \mathrm{a}$ $930 \mathrm{~L} \mathrm{~kg}^{-1}$ (Roberts et al., 1998).

\subsection{Pesticidas e Ambiente}

Com o objetivo de se obter altos índices de produtividade, o sistema de produção agrícola atual faz uso intensivo de insumos, com destaque para os pesticidas. Neste contexto, os herbicidas têm se tornando um componente fundamental para assegurar produção em quantidade e qualidade desejáveis. Paralelamente, em virtude dos avanços tecnológicos e pressões ambientalistas, a indústria química tem produzido novos pesticidas com características físico-químicas que proporcionam modos de ação diferenciados e comportamentos ambientais distintos, com grandes alterações nos perfis toxicológicos e ecotoxicológicos (ARMAS et al., 2005). 
Porém, é preciso atentar para o fato de que o uso inadequado destes pesticidas sejam eles, herbicidas, inseticidas, fungicidas, nematicidas, etc, pode levar à contaminação ambiental. Dentre os compartimentos ambientais que podem sofrer com a contaminação por pesticidas, vale destacar os recursos hídricos, uma vez que estes estão em via de se tornarem escassos em algumas regiões do planeta em curto período de tempo. Aliadas ao uso intensivo e indiscriminado de pesticidas, certas práticas agrícolas como a destruição da cobertura vegetal dos solos para o plantio, a devastação de matas ciliares e de vegetações protetoras de nascentes, dentre outros fatores, contribuem significativamente com o problema de contaminação de recursos hídricos (TOMITA; BEYRUTH, 2002).

Segundo Ahmad, Kookana e Alston (2001), os herbicidas predominam entre os pesticidas detectados em águas subterrâneas. Além disso, devido ao alto volume de herbicidas utilizado e também ao fato de muitos herbicidas serem aplicados em áreas próximas a cursos d'água, é comum encontrar resíduos destes herbicidas em águas superficiais (TOMITA; BEYRUTH, 2002).

Uma vez na água, dependendo de suas características físico-químicas, o pesticida pode tanto se ligar ao material particulado em suspensão, como se depositar no sedimento do fundo ou ser absorvido por organismos, podendo então ser detoxicados ou acumulados. No sistema aquático, eles podem ser transportados por difusão nas correntes de água ou nos corpos dos organismos aquáticos. Alguns pesticidas e/ou metabólitos (produtos da degradação dos pesticidas) podem ainda retornar à atmosfera por volatilização. Desta forma, fica claro que há uma interação contínua entre pesticidas, sedimento e água, e que esta interação é influenciada pelo movimento da água, turbulência e temperatura (TOMITA; BEYRUTH, 2002).

Inúmeros trabalhos têm comprovado a presença de níveis significantes de pesticidas e/ou seus metabólitos em solos, atmosfera, águas subterrâneas e rios de vários países (BLANCHOUD, 2004), mas pouco tem sido estudado no Brasil. Segundo Garmouma et al. 
(1997), vários estudos revelaram a presença de atrazinas em águas subterrâneas. Ainda segundo estes autores, foram encontrados resíduos de quatro tipos de triazinas nas águas do Mélarchez (França): atrazina, simazina, ametrina e terbutrina nos anos de 1991 a 1993.

Nos Estados Unidos, em 1988, um estudo revelou que mais da metade dos estados americanos possuíam águas subterrâneas contaminadas (PARSONS; WITT, 1989; UETA et al., 2004). No estado da Georgia (EUA), foi detectada a presença de pesticida tanto na água de escoamento superficial quanto no fluxo descendente de água no solo (INOUE et al., 2003). $\mathrm{Na}$ ilha da Martinica (França), foram encontrados resíduos de triazinas (simazina e ametrina) em rios (BOCQUENÉ; FRANCO, 2005).

Liu, Fernadez-Horta e Santiago-Cordova ${ }^{1}$ (1991, apud McDonald et al., 1999, p. 182) encontraram resíduos de ametrina em sedimentos, sugerindo que a maioria da ametrina ficou sorvida nas partículas do solo. Por outro lado, Green et al. (1977) detectaram que a ametrina dispersou-se rapidamente no campo e não foi encontrada em sedimentos e águas superficiais.

No Brasil, um estudo desenvolvido pela SUREHMA (Superintendência dos Recursos Hídricos e Meio Ambiente) no Estado do Paraná, no período de 1976 a 1984, constatou que 84\%, de um total de 1825 amostras de água colhidas nos rios apresentaram resíduos de pesticidas e que $78 \%$ destas amostras encontravam-se "contaminadas" mesmo depois dos tratamentos convencionais de água (DE LUNA; DE SALES; DA SILVA, 2007). Análises de água de uma área com plantação de cana-de-açúcar, na bacia do Espraiado, região de Ribeirão Preto (SP), mostraram a presença de resíduos de ametrina em 17 pontos amostrados (CERDEIRA et al., 1998). Num outro estudo realizado no Parque Turístico do Alto Ribeira (Petar), no estado de São Paulo, detectou-se que a fauna e a flora estavam expostas aos pesticidas que se encontram dissolvidos na água ou presentes no sedimento (TOMITA; BEYRUTH, 2002).

\footnotetext{
${ }^{1}$ LIU, L.; FERNANDEZ-HORTA, D.; SANTIAGO-CORDOVA. Diuron and ametryn runoff from a plantain field. Journal of Agriculture of the University of Puerto Rico, v.69, 9,117-183, 1991.
} 
Ainda no Brasil, Laabs et al. (2002), concluíram que na área da bacia do Pantanal, a atmosfera representa importante porta de entrada de pesticidas nos ecossistemas, inclusive na água, diferentemente do que ocorre em regiões temperadas, reafirmando a necessidade de mais estudos em condições ambientais brasileiras.

\subsection{Os processos de sorção/dessorção de pesticidas}

Os processos de sorção/dessorção dos pesticidas exercem papel fundamental sobre o movimento e a persistência dos mesmos no solo. A sorção do pesticida afeta diretamente o seu transporte no solo à medida em que retarda a sua migração e, indiretamente, pela diminuição das taxas de degradação (biótica e abiótica) em decorrência da redução da disponibilidade dos pesticidas na solução do solo (HUANG et al., 2004). A melhor compreensão destes processos pode levar ao uso mais eficiente dos pesticidas e, consequentemente, à redução de resíduos (QUEIROZ; LANÇAS, 1997).

A sorção é um fenômeno físico-químico que se refere aos processos de retenção de forma geral, sem distinção aos processos específicos de adsorção, absorção, precipitação ou partição hidrofóbica. (REGITANO, 2002). A adsorção é o processo reversível que ocorre quando moléculas do pesticida são atraídas para a superfície da matéria sólida ou para a matéria orgânica do solo por mecanismos químicos ou físicos (LAVORENTI; PRATA; REGITANO, 2003). A absorção, por sua vez, é um fenômeno puramente físico que consiste na penetração de moléculas do pesticida nos espaços microscópicos do solo (PARAÍBA; LUIZ; PÉREZ, 2005). A partição hidrofóbica diz respeito à afinidade de determinada molécula orgânica pela fração orgância do solo, devido à sua baixa afinidade pela solução do solo. Por fim, o processo de dessorção é o processo inverso ao processo de sorção, ou seja, é o 
retorno de parte da fração sorvida para a solução do solo (LAVORENTI; PRATA; REGITANO, 2003).

Por se tratar de moléculas orgânicas, o mecanismo de sorção dos pesticidas é muito mais complexo do que o dos íons que servem como nutrientes para as plantas. Forças físicas como forças eletrostáticas, forças de van der Waals, pontes de hidrogênio, ligações covalentes e interações hidrofóbicas são os principais mecanismos que podem contribuir com a sorção dos pesticidas; sendo que estes mecanismos podem atuar ao mesmo tempo na sorção de um mesmo pesticida (PARAÍBA; LUIZ; PÉREZ, 2005).

Para moléculas que se ionizam (triazinas, imazaquim, etc.) e para aquelas que já possuem cargas em sua estrutura, como o paraquat e diquat, pode-se destacar as ligações eletrostáticas. As ligações covalentes se destacam para moléculas que apresentam grupos fosfônicos com os óxidos e hidróxidos de ferro e alumínio do solo (glifosato, por exemplo) (CHEAH; KIRKWOOD; LUM, 1997). A interação hidrofóbica dos herbicidas com a matéria orgânica do solo tem maior relevância para moléculas apolares (sulfoniluréias), mas não deixa de ser importante para todas as outras moléculas (GROVER, 1975). Já as forças físicas, como as van der Waals e as pontes de hidrogênio, estão sempre atuando sobre as moléculas, independentemente do envolvimento de outros mecanismos de ligação.

O processo de sorção pode ser influenciado por várias características do solo, tais como, conteúdo de carbono orgânico, pH e conteúdo e tipo de argila (AHMAD; KOOKANA; ALSTON, 2001). Além disso, depende fortemente das características intrínsecas do pesticida: forma, $\mathrm{pKa}$ ou $\mathrm{pKb}$ (acidez ou alcalinidade), solubilidade em água, polaridade e tamanho da molécula (QUEIROZ; LANÇAS, 1997). Por fim, as condições climáticas (umidade e temperatura) também exercem influência sobre os processos de sorção/dessorção de pesticidas em solo (HABERHAUER et al., 2001). 
A sorção de pesticidas ácidos, básicos ou catiônicos é influenciada pelo pH do solo aumentando ou diminuindo as forças de atração entre as moléculas do pesticida e a matéria orgânica ou matéria sólida do solo. A sorção de pesticidas iônicos é fortemente dependente do conteúdo de carbono orgânico do solo, pois a matéria orgânica do solo é constituída por inúmeras substâncias quimicamente ativas (PARAÍBA; LUIZ; PÉREZ, 2005).

Além disso, fração significativa dos pesticidas permanece no solo como resíduo ligado, o qual não é passível de extração por métodos que não alterem significativamente a natureza da molécula, sendo a matéria orgânica, a principal responsável pela formação desses resíduos (PRATA et al., 2001).

\subsection{O processo de lixiviação de pesticidas}

O processo de lixiviação corresponde ao movimento descendente dos pesticidas na solução do solo, sendo sua intensidade dependente das características físico-químicas do pesticida (solubilidade em água, hidrofobicidade) e das características do solo (textura e estrutura) e do clima (índice pluviométrico) (FUTCH; SINGH, 1999).

Para sofrer lixiviação, o pesticida tem que estar na solução do solo ou adsorvido às partículas de baixo peso molecular, tais como, argilas, ácidos fúlvicos e húmicos, aminoácidos, peptídeos e açúcares (INOUE et al., 2003). Neste sentido, o potencial de lixiviação é maximizado quando pesticidas de alta solubilidade são aplicados em solos arenosos, com baixo conteúdo de matéria orgânica (FUTCH; SINGH, 1999).

O risco de ocorrência de pesticidas em águas subterrâneas tem mostrado a necessidade de estudos sobre os processos de transporte desses compostos nos solos. Tais estudos devem enfocar os processos de lixiviação e de escoamento superficial. Considerando que a principal parte do fluxo de massa no solo ocorre durante a primeira chuva, após a aplicação dos 
pesticidas, a perda por meio da lixiviação durante uma chuva pode ser assumida como sendo comparável à perda por escoamento superficial (FLURY, 1996).

Foi apenas na última década, que o processo de lixiviação foi considerado importante no que diz respeito à contaminação de águas subterrâneas (SMITH; JOHNSON; PEPPERMAN, 2001); até então, este risco era considerado nulo (BOUWER, 1990). No que diz respeito aos mananciais aquáticos, principalmente os subsuperficiais, a lixiviação de pesticidas é uma das principais formas de contaminação. A lixiviação excessiva contribui, em muitos casos, para que o pesticida atinja e contamine o lençol freático (INOUE et al., 2003).

Pesquisas conduzidas na última década em aqǘferos dos Estados Unidos mostraram contaminação por vários compostos orgânicos e inorgânicos (CERDEIRA et al., 2005). Em amostras de água do rio Mississippi (EUA), foi constatada a presença do fungicida clorotalonil e de seu metabólito hidroxiclorotalonil (PEREIRA; ROSTAD, 1990). Segundo Langenbach, Schroll e Paim (2000), a atrazina é o herbicida mais encontrado em cursos d'água no mundo. Inúmeras pesquisas sobre a contaminação de cursos d'água por pesticidas podem ser encontradas na literatura, porém, informações desta natureza são escassas para as condições brasileiras.

Segundo Enfield (1985), o movimento vertical de moléculas hidrofóbicas também é possível. Estas moléculas podem se ligar a macromoléculas orgânicas solúveis em água e serem desta forma, lixiviadas no perfil do solo. Neste caso, a lixiviação seria da fração resíduo ligado do pesticida, e não do pesticida propriamente dito (BARRIUSO; HOUOT; SERRAWITTLING, 1997). 


\subsection{0 lodo de esgoto na agricultura}

O tratamento dos esgotos resulta na produção de um resíduo rico em matéria orgânica e nutrientes, o chamado lodo de esgoto ou biossólido (CAMARGO; BETTIOL, 2000). A composição deste lodo depende da sua origem, do processo e grau de tratamento, do tipo de lodo etc (TSUTIYA, 2002b; OLIVEIRA et al., 2006). Um lodo típico tem cerca de 40\% de matéria orgânica, $4 \%$ de nitrogênio, $2 \%$ de fósforo e os demais macro e micronutrientes, além de elementos potencialmente tóxicos, metais pesados e patógenos humanos (CAMARGO; BETTIOL, 2000).

O processo de tratamento do esgoto consiste na separação da fase sólida (matéria orgânica) da fase líquida. Para isto, várias etapas sãos seguidas, conforme descrito no quadro abaixo.

\begin{tabular}{|c|l|l|l|}
\hline \multicolumn{1}{|c|}{ Etapas } & \multicolumn{1}{|c|}{ Funções } & \multicolumn{1}{|c|}{ Principais Processos } \\
\hline Adensamento & - remoção de água (redução do & - adensamento por gravidade \\
& volume) & - flotação \\
& & - centrífuga \\
\hline Estabilização & - redução de patógenos & - filtro prensa de esteiras \\
& - eliminação de maus odores & - digestão anaeróbia / aeróbica \\
& Separação das fases sólido-líquida & - condicionamento térmico \\
& (preparação para a desidratação) & -estabilização química \\
\hline Condicionamento & melhoria das características de & - condicionamento químico \\
\hline
\end{tabular}




\begin{tabular}{|c|c|c|}
\hline Etapas & Funções & Principais Processos \\
\hline Desaguamento & $\begin{array}{l}\text { - remoção de água (redução do } \\
\text { volume) }\end{array}$ & $\begin{array}{l}\text { - leitos de secagem } \\
\text { - lagoas de lodo } \\
\text { - filtro prensa / de esteiras } \\
\text { - centrífuga } \\
\text { - filtro a vácuo } \\
\text { - secagem térmica }\end{array}$ \\
\hline Higienização & - remoção de patógenos & $\begin{array}{l}\text { - adição de cal } \\
\text { - tratamento térmico } \\
\text { - compostagem } \\
\text { - oxidação úmida } \\
\text { - radiação gama } \\
\text { - solarização }\end{array}$ \\
\hline
\end{tabular}

Quadro 1. Etapas, funções e principais processos utilizados no tratamento do esgoto (DOS SANTOS, 2003).

Em decorrência do crescente número da população, o volume de lodo de esgoto gerado tem crescido nas últimas décadas. Segundo Oliveira et al. (2006), os decantadores primários de uma estação de tratamento de esgoto produzem de 2500 a 3500 litros de lodo por milhão de litros de esgoto tratado. Tal fato se tornou um problema ambiental, pois a sua disposição em aterros sanitários, prática mais rotineira até então, tornou-se financeira e ambientalmente inviáveis. Para a região metropolitana de São Paulo, estima-se a produção de $766 \mathrm{t} \mathrm{dia}^{-1}$ (base seca) de biossólidos para o ano de 2015 (MELO; MARQUES; MELO, 2002).

O problema da gestão do lodo de esgoto, de grande complexidade técnica e com custos significativos nos procedimentos operacionais, passou a ser gerenciado em situações de crise pelas áreas operacionais, que inicialmente armazenam este material em áreas próximas às ETEs e quando a quantidade vai aumentando, utilizam-se de todos os meios para se livrar 
emergencialmente dos resíduos gerados. Desta forma, não é raro se encontrar lodo armazenado em condições precárias, com a simples distribuição para agricultores sem critérios de segurança, chegando até ao absurdo técnico do seu simples lançamento nos cursos d'água (ANDREOLI; PEGORINI, 1998). Segundo Andreoli e Pegorini (1998), a disposição final adequada do lodo de esgoto pode corresponder a $60 \%$ dos custos de uma estação de tratamento de esgoto.

As práticas mais comuns para o aproveitamento ou disposição final do lodo são a disposição em aterro sanitário, a reutilização industrial (produção de tijolo, cerâmica e cimento), a incineração, a conversão em óleo combustível, a disposição nos oceanos, a recuperação de solos e o uso agrícola e florestal (CAMARGO; BETTIOL, 2000; TSUTIYA, 2002a). A disposição de lodo de esgoto na agricultura é uma prática antiga. As informações mais conhecidas são oriundas da China. No ocidente, sabe-se que na Prússia, a irrigação com efluentes de esgotos era praticada desde 1560. Na Inglaterra, muitos projetos para a utilização agrícola dos efluentes de esgoto foram desenvolvidos por volta de 1800 (CAMARGO; BETTIOL, 2000).

A aplicação do lodo de esgoto na agricultura tem como principal benefício, a incorporação de macronutrientes (nitrogênio e fósforo) e micronutrientes (zinco, cobre, ferro, manganês e molibdênio) ao solo. Além disso, esta prática melhora as condições físicas do solo, aumentando a retenção de água em solos arenosos, melhorando a permeabilidade e infiltração em solos argilosos, mantendo boa estrutura e estabilidade dos agregados na superfície do solo (BETTIOL; CAMARGO, 2006; ANTONIOUS; PATTERSON; SNYDER, 2003).

Embora em pequeno número, alguns estudos realizados no Brasil demonstram que o lodo é um resíduo com potencial de uso agrícola. Silva, Resck e Sharma (2000) mostraram que o lodo de esgoto tem potencial para substituir fertilizantes minerais na cultura de milho no 
cerrado brasileiro. Melo e Marques (2000) apresentam informações sobre a utilização de lodo como fornecedor de nutrientes para as culturas de cana-de-açúcar, milho, sorgo e azevém. Bettiol e Camargo (2000) também estudaram os benefícios da aplicação de lodo de esgoto em várias culturas: aveia, trigo, pastagens, feijão, soja, café e pêssego. Por sua vez, Gonçalvez et al. (2000) analisaram a utilização de lodo em áreas florestais, mais precisamente, no cultivo de eucalipto.

Até o momento, muitos estudos foram feitos avaliando-se a influência da aplicação de lodo de esgoto sobre as propriedades físico-químicas do solo, no entanto, muito pouco tem sido feito para avaliar a influência do lodo de esgoto no comportamento de pesticidas no solo. De uma forma geral, a aplicação de lodo de esgoto aumenta as quantidades de carbono orgânico solúveis (dissolvido, COD) e insolúveis (sólido, COI) no solo. Por um lado, a fração orgânica insolúvel pode aumentar a sorção do pesticida, sendo uma boa prática para evitar perdas por lixiviação (MORILLO et al., 2002; SÁNCHEZ; ROMERO; ARÁNZAZU, 2003). Por outro lado, a adição da fração orgânica dissolvida reduz a sorção do pesticida devido às interações entre as moléculas de pesticida e de COD (complexação micelar) e à competição dessas moléculas pelos sítios de sorção do solo (CELIS; BARRIUSO; HOUOT, 1998; BRICEÑO; PALMA; DURÁN, 2007). 


\section{SORÇÃO E DESSORÇÃO DO HERBICIDA AMETRINA EM SOLOS CANAVIEIROS TRATADOS COM LODO DE ESGOTO}

\section{Resumo}

Vários estudos têm mostrado os benefícios da aplicação agronômica de lodo de esgoto sobre as propriedades físicas e químicas do solo. No entanto, poucos são aqueles que avaliam o impacto desta prática sobre o comportamento de pesticidas em solos tropicais. O principal objetivo deste estudo foi avaliar o efeito da adição de diferentes fontes de lodo (Ribeirão Preto, Franca e Jundiaí) na sorção e dessorção do herbicida ametrina em solos canavieiros do estado de São Paulo (Neossolo Quartzarênico Órtico Típico (RQ), Latossolo Vermelho Distrófico Típico (LVd), Argissolo Vermelho Eutroférrico Chernossólico (PV) e Latossolo Vermelho Distroférrico (LVdf)). Cinco concentrações (de 4,4 a 79,8 mg i.a. $\mathrm{L}^{-1}$ ) do herbicida foram utilizadas para obter os valores dos coeficientes de sorção de Freündlich $\left(\mathrm{K}_{\mathrm{f}}\right)$ e dos coeficientes aparentes de sorção médio e para a menor concentração $\left(K_{d}{ }^{a p}{ }_{\text {médio }}\right.$ e $\left.K_{d}{ }^{a p}{ }_{[m e n o r]}\right)$, a qual corresponde à dose de campo recomendada. De forma geral, a sorção da ametrina variou de moderada à alta em todos os tratamentos $\left(2,68<\mathrm{K}_{\mathrm{d}}{ }_{[\text {menor }]}<85,71 \mathrm{~L} \mathrm{~kg}^{-1}\right)$. Solos argilosos com maior teor de matéria orgânica e argilas do tipo 2:1, como é o caso do PV, apresentaram muito maior potencial de sorção da ametrina; enquanto que solos arenosos com baixos teores de matéria orgânica, como foram os casos do LVd e RQ, apresentaram moderado potencial de sorção. A aplicação de lodos menos estabilizados, com biomassa e material orgânico menos recalcitrante e, portanto, com maiores valores de carbono orgânico total, carbono orgânico dissolvido e pH, como é o caso do lodo de Ribeirão Preto, tendeu a diminuir o potencial de sorção da ametrina. Já a adição de lodos mais recalcitrantes, como o de Jundiaí, tendeu a aumentar o potencial de sorção da ametrina, principalmente em solos arenosos devido a sua 
menor capacidade tampão. Nestes cenários, poderá ocorrer redução da eficácia agronômica ametrina, uma vez que haverá menos produto disponível na solução do solo. Por outro lado, o potencial de lixiviação da ametrina será reduzido.

Palavras-chave: retenção, pesticida, triazina, resíduo orgânico, carbono orgânico dissolvido. 


\section{Abstract}

Several studies have shown the benefits of applying sewage sludge on the physical and chemical properties of the soils. However, just a few of them evaluates the impact of this practice on the behavior of pesticides in tropical soils. The main goal of this research was to evaluate the effects of applying different sources of sewage sludge (Ribeirão Preto, Franca e Jundiaí) on the sorption and desorption of ametryne in soils from São Paulo state (Brazil) cultivated with sugarcane (Neossolo Quartzarênico Órtico Típico (RQ), Latossolo Vermelho Distrófico Típico (LVd), Argissolo Vermelho Eutroférrico Chernossólico (PV) e Latossolo Vermelho Distroférrico (LVdf)). Five concentrations (4.4 to $79.8 \mathrm{mg}$ a.i. $\mathrm{ha}^{-1}$ ) of the herbicide were applied to the soil samples to attain the Freündlich sorption coefficients $\left(\mathrm{K}_{\mathrm{f}}\right)$ and the apparent sorption coefficient for the lower concentration $\left(\mathrm{K}_{\mathrm{d}}{ }^{\mathrm{ap}}{ }_{[\mathrm{menor}]}\right)$, which corresponded to the field application rate. In general, ametryne sorption ranged from moderate to high in all treatments $\left(2.68<\mathrm{K}_{\mathrm{d}}{ }_{[\text {menor] }}^{\mathrm{ap}}<85.71 \mathrm{~L} \mathrm{~kg}^{-1}\right)$. Clay soils with higher organic matter and 2:1 clay contents, such as the PV, showed much higher sorption potential, whereas sand soils with low organic matter content, such as LVd and RQ, showed moderate sorption potential. The application of less stabilized sewage sludges, with less recalcitrant biomass and organic material and, therefore, with higher organic matter and dissolved organic carbon contents and $\mathrm{pH}$ values, such as the Ribeirão Preto, tends to decrease ametryne sorption potential. Otherwise, the addition of more recalcitrant sludges, such as the Jundiaí, tends to enhance its sorption potential, mainly in sand soils due to its lower buffer capacity. In those cases, the agronomic efficacy of ametryne may be reduced since there is lower concentration of the compound available in the soil solution. On the other hand, its leaching potential may be reduced.

Key words: retention, pesticide, triazine, organic residues, dissolved organic carbon 


\subsection{INTRODUÇÃO}

O consumo mundial de pesticidas está em constante crescimento (ARMAS et al.; 2005). Inúmeros trabalhos revelam a contaminação dos recursos naturais por estes produtos em decorrência de seu uso indiscriminado. Por exemplo, Bittencourt (2007) reporta que o uso indiscriminado de pesticidas tem provocado o seu acúmulo na água, no solo e no ar, conduzido a diversos problemas relacionados à contaminação ambiental e saúde pública, com os respectivos custos sociais decorrentes: destacando-se a contaminação de alimentos e, principalmente, as intoxicações entre os que trabalham diretamente com pesticidas.

Paralelamente, a atividade humana gera constantemente resíduos, sejam eles decorrentes de seu próprio metabolismo ou da atividade industrial, que aumentam em decorrência do crescimento populacional. No início, os resíduos gerados limitavam-se às sobras alimentares, aos dejetos humanos e aos restos de uma agricultura incipiente, resíduos estes, que a própria natureza se encarregava de reciclar. Com o passar do tempo, foram surgindo os grandes centros urbanos que trouxeram consigo as indústrias, o que além de aumentar a geração de resíduos, aumentou o consumo de água e a produção de esgoto (MELO; MARQUES; MELO, 2002; BRICEÑO; PALMA; DURÁN, 2007).

Nestas circunstâncias, a natureza deixou de ser auto-suficiente no papel de recicladora de resíduos, exigindo do ser humano providências para impedir que córregos e rios se tornem esgotos a céu aberto. Assim, o tratamento de águas servidas ou residuárias tornou-se necessário. Porém, este tratamento colocou o homem frente a um novo problema: a geração do lodo de esgoto (MELO; MARQUES; MELO, 2002; BRONDI; LANÇAS, 2004).

O lodo de esgoto (biossólido), resultante do processo de tratamento do esgoto, necessita de uma disposição final adequada. Porém, vários projetos de tratamento não levam em consideração o destino final do lodo produzido e com isso anulam-se parcialmente os 
benefícios da coleta e do tratamento dos efluentes (CAMARGO; BETTIOL, 2000). Assim, é preciso desenvolver pesquisas científicas e tecnológicas com o intuito de se obter alternativas seguras para que esse produto não se transforme num novo problema ambiental.

Egiarte et al. (2006) afirmam que a aplicação de lodo de esgoto em áreas agrícolas se tornou uma alternativa de disposição muito atrativa, devido ao fato de ser uma forma sustentável de gerenciamento deste resíduo, uma vez que envolve a reciclagem de matéria orgânica e nutrientes presentes no lodo de esgoto. Por outro lado, entre as principais limitações na disposição do lodo de esgoto no solo estão os riscos de contaminação do solo com agentes patogênicos, metais pesados e compostos orgânicos, além da lixiviação de nitrogênio e arraste de fósforo, os quais podem contaminar o lençol freático e as águas superficiais (DOS SANTOS, 2003; BRICEÑO; PALMA; DURÁN, 2007). Além disso, por ser um fertilizante orgânico "em potencial”, possível de ser aplicado em quantidades significativas $\left(\mathrm{t} \mathrm{ha}^{-1}\right)$, existe a possibilidade de esta prática provocar redução na eficácia agronômica dos herbicidas empregados em pré-emergência, provavelmente devido ao aumento na sorção destes produtos aos solos tratados com lodo, uma vez que ocorre aumento inicial no teor de carbono orgânico. No entanto, vem sendo ignorada a influência da aplicação de lodo de esgoto no comportamento dos pesticidas.

O processo de sorção afeta diretamente o transporte de pesticidas no solo pelo retardamento da migração e, indiretamente, pela redução das taxas de degradação (HUANG et al., 2004; BOESTEN, 1991). A sorção protege o pesticida da degradação e reduz o seu transporte no solo, enquanto que o processo de dessorção exerce o papel reverso, embora a cinética de sua reação seja muito mais lenta (FERNANDES et al., 2006). O valor do coeficiente de sorção $\left(\mathrm{K}_{\mathrm{d}}\right)$ serve de parâmetro para alimentar praticamente todos os modelos matemáticos, os quais visam estimar, por exemplos, a lixiviação, a volatilidade, a fotodegradação (em estado adsorvido às superfícies de aerossóis) e o escoamento superficial 
do pesticida para um determinado compartimento do ambiente (PINTO; JARDIM, 2004). Geralmente, quanto maior for a sorção de um pesticida ao solo, menor será a sua disponibilidade e a sua taxa de degradação e, consequentemente, menor será a sua mobilidade, sendo menores as chances deste herbicida alcançar águas superficiais e/ou subterrâneas.

Diversos são os trabalhos que enfatizam a influência da matéria orgânica sobre a sorção e a persistência de pesticidas no solo (BARRIUSO, 1997; REGITANO et al., 2000). A adição de qualquer tipo de material orgânico ao solo irá influenciar diretamente o comportamento ambiental de um pesticida, podendo torná-lo mais persistente devido ao incremento no potencial de sorção do solo, ou degradá-lo mais rapidamente devido à aceleração na atividade microbiana deste mesmo solo (REGITANO et al., 2002; BRICEÑO; PALMA; DURÁN, 2007). Portanto, maior atenção deve ser dada à incorporação de resíduos orgânicos ao solo, como por exemplo o lodo de esgoto, uma vez que isto irá influenciar diretamente a dinâmica do pesticida no ambiente.

A adição de lodo de esgoto ao solo eleva tanto as quantidades de materiais orgânicos solúveis quanto insolúveis, tornando difícil prever seu efeito sobre o comportamento de pesticidas no solo. Na literatura, existem trabalhos que mostram que a capacidade de sorção de compostos orgânicos é aumentada quando se adiciona lodo de esgoto ao solo, ao mesmo tempo em que outros demonstram que o potencial de lixiviação dos pesticidas é aumentado (DE JONGE et al., 2002). Naturalmente esses fenômenos dependem da natureza do material orgânico, o que no caso dos lodos de esgoto pode estar intimamente relacionado com sua origem, concepção de tratamento dos esgotos, métodos de estabilização e de desaguamento etc.

Alguns estudos têm demonstrado que a adição de materiais orgânicos solúveis ao solo promove redução no potencial de sorção do herbicida ao solo, conseqüentemente, aumentando 
o seu potencial de lixiviação (Celis, Barriuso e Houot, 1998, BRICEÑO; PALMA; DURÁN, 2007). Por outro lado, a adição de materiais orgânicos mais estabilizados (insolúveis) ao solo, promove o aumento na sorção do herbicida (GRABER et. al., 2001; MORILLO et al., 2002; SÁNCHEZ et al., 2003; BRICEÑO; PALMA; DURÁN, 2007). Guo et al. (1993), Barriuso et al. (1997), Sluszny et al. (1999) e Graber et al. (2001) detectaram que a sorção de vários pesticidas aumentou com a adição de matéria orgânica ao solo.

Por ser a cultura da cana-de-açúcar aquela de maior potencial para reciclagem agrícola do lodo de esgoto, essencialmente pela significativa área ocupada no Brasil, nível tecnológico e caráter industrial e sendo a ametrina um dos principais herbicidas utilizados nesta cultura, seu comportamento no ambiente merece ser melhor estudado em condições tropicais. Trabalhos de outros países mostraram que a atrazina, o bromacil, a simazina, a ametrina, e o norflurazon foram os pesticidas detectados em maior freqüência em amostras de água de 27 estações no sul da Flórida (MILES; PFEUFFER,1997). Por outro lado, Sluszny et al. (1999) e Briceño, Palma e Durán (2007) detectaram aumento na sorção da ametrina em solos tratados com lodo de esgoto, o que reduziria o seu potencial de lixiviação. Nesse contexto, este trabalho estudou a influência da aplicação de lodo de esgoto de diferentes origens nos processos de sorção/dessorção do herbicida ametrina em solos canavieiros, com diferentes teores de carbono orgânico $\left(\mathrm{C}_{\mathrm{org}}\right)$ e argila. 


\subsection{MATERIAIS E MÉTODO}

\section{Ametrina}

A ametrina (2-etilamino-4-isopropilamino-6-metiltio-s-triazina) é um herbicida seletivo sistêmico, inibidor da fotossíntese, pertencente ao grupo das triazinas, usado em pré- e pósemergência para controlar plantas daninhas anuais (folhas estreitas e largas), associadas às culturas de cana-de-açúcar e citros, entre outras.

Trata-se de um herbicida ionizável, com caráter básico $\left(\mathrm{pK}_{\mathrm{a}}=4,1\right)$; solubilidade em água $=200 \mathrm{mg} \mathrm{L}^{-1}$ a $25{ }^{\circ} \mathrm{C}$; pressão de vapor $=3,7 \times 10^{-4} \mathrm{~Pa} ; \log \mathrm{K}_{\mathrm{ow}}=2,63$ e $\mathrm{K}_{\mathrm{oc}}=100 \mathrm{a}$ $930 \mathrm{~L} \mathrm{~kg}^{-1}$ (ROBERTS et al., 1998). Apresenta alta estabilidade em meios neutros, levemente ácidos ou levemente alcalinos. No solo, este herbicida está sujeito primariamente à degradação microbiana, sendo relativamente persistente $\left(\mathrm{DT}_{50}=70\right.$ a 129 dias). A dose de aplicação normalmente recomendada varia de 2,25 a 3,0 kg i.a. ha ${ }^{-1}$, dependendo da textura do solo.

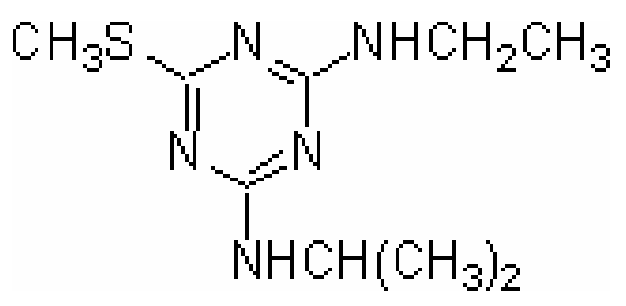

Figura 1. Fórmula estrutural da ametrina.

Para este estudo, foi utilizada uma molécula radiomarcada: ${ }^{14} \mathrm{C}$-ametrina, com atividade específica igual a $1,05 \mu \mathrm{Ci} \mathrm{mg}{ }^{-1}$ e $95 \%$ de pureza, sendo que a dose de campo adotada correspondeu a $3 \mathrm{~kg}$ i.a. $\mathrm{ha}^{-1}$. 


\section{Solo}

Foram utilizados quatro tipos de solos com diferentes propriedades físico-químicas e com representação dentro da região canavieira do Estado de São Paulo: Neossolo Quartzarênico Órtico Típico (RQ), Latossolo Vermelho Distrófico Típico (LVd), Argissolo Vermelho Eutroférrico Chernossólico (PV) e Latossolo Vermelho Distroférrico (LVdf). As amostras de solo foram coletadas na camada de 0,0 - 0,2 $\mathrm{m}$ de profundidade, secas ao ar e passadas em peneira com $2 \mathrm{~mm}$ de diâmetro e, posteriormente, encaminhadas para o Departamento de Ciência do Solo / ESALQ / USP para realização das análises de suas propriedades físico-químicas (Tabela 1).

Para a análise granulométrica, foi utilizado o método do densímetro, enquanto que o alumínio trocável e os cátions trocáveis foram extraídos com $\mathrm{KCl} 1 \mathrm{~mol} \mathrm{~L}^{-1}$ e resina trocadora de íons, respectivamente. $\mathrm{O} \mathrm{pH}$ foi determinado em $\mathrm{CaCl}_{2} 0,01 \mathrm{~mol} \mathrm{~L}^{-1}$ e a acidez potencial $(\mathrm{H}+\mathrm{Al})$ foram estimadas com o uso do tampão SMP. O teor de matéria orgânica foi estimado com o uso do método colorimétrico (CAMARGO et al., 1986; MALAVOLTA; VITTI; DE OLIVEIRA, 1989; RAIJ; QUAGGIO, 1983). Além disso, foi feita uma prévia análise dos minerais de argila através de difratogramas de raio-x.

\section{Lodo de esgoto}

Três amostras de lodos de esgoto foram selecionadas com base em sua origem, na sua representatividade e potencial para reciclagem agrícola nos solos canavieiros do Estado de São Paulo, bem como nos resultados contrastantes de um estudo preliminar realizado com dez tipos de lodo de esgoto. Os lodos selecionados são oriundos de estações de tratamento 
biológico de esgotos das cidades paulistas de Jundiaí (Companhia Saneamento de Jundiaí), Franca (Companhia de Saneamento Básico do Estado de São Paulo) e Ribeirão Preto (Ambient Ribeirão Preto S.A.). As amostras foram coletadas e armazenadas em sacos plásticos à $\pm 5{ }^{\circ} \mathrm{C}$. Sub-amostras foram enviadas ao Departamento de Ciências Exatas / Laboratório de Química / ESALQ / USP para caracterização de suas propriedades químicas (Tabela 2).

A determinação do nitrogênio foi feita de acordo com o método oficial empregado para fertilizantes orgânicos (BRASIL, 1988). O carbono orgânico total $\left(\mathrm{C}_{\mathrm{org}}\right)$ foi determinado com base na oxidação do mesmo por dicromato de potássio por via úmida, na presença de ácido sulfúrico e com aquecimento externo (RODELLA, 1996). Os teores totais de fósforo, potássio, sódio, cálcio, magnésio, cobre e zinco foram determinados em extratos nítricoperclórico de amostras secas e moídas. O teor de carbono orgânico dissolvido (COD) foi determinado com base na conversão do carbono orgânico total em $\mathrm{CO}_{2}$ e detecção por célula de infravermelho não dispersivo (Equipamento TOC $5000 \mathrm{~A}$ - Shimadzu). As amostras foram previamente purgadas com ar sintético 5.0 e $\mathrm{HCl} 2 \mathrm{~N}$ para retirada do carbono inorgânico.

O processo de tratamento de esgoto utilizado na ETE Franca é o de lodos ativados convencional. O lodo do decantador primário é misturado ao excesso de lodo biológico, proveniente do tanque de aeração. Após espessamento em adensadores gravimétricos, o lodo é introduzido em digestores onde ocorre a estabilização através do processo de digestão anaeróbia. Por fim, o lodo condicionado com polímeros passa por filtro prensa de esteira e tem o seu grau de umidade reduzido para 80\% (VANDO; MACEDO; TSUTIYA, 2000).

A ETE de Jundiaí é concebida por lagoas aeradas de mistura completa, seguidas de lagoas de sedimentação. O lodo biológico é dragado continuamente das lagoas de sedimentação, porém, uma particularidade operacional implementada após o início das atividades da ETE e o início da retirada e desaguamento de lodo, fez com que o lodo tenha 
permanência média de 12 meses no fundo destas lagoas, visando aumentar o seu grau de digestão através de processos anaeróbios. Na seqüência, o mesmo é destinado para tanques de equalização e injetado simultaneamente com suspensão de polímeros em centrífugas para seu desaguamento. O lodo desaguado é encaminhado para um pátio de secagem ao ar com revolvimento mecânico diário, onde permanece por período médio de 60 dias atingindo teores de sólidos próximos a 40 \% (informação pessoal) $)^{2}$.

Na ETE de Ribeirão Preto, de concepção de lodos ativados convencional, o esgoto passa por gradeamento grosso, intermediário e fino, seguindo para um desarenador e desengordurador. Em seguida, o lodo de esgoto segue para o decantador primário, onde ocorre a separação de sólidos sedimentáveis e dissolvidos, e vai para o reator biológico para sofrer o tratamento biológico. Após este tratamento, o lodo passa por decantadores e segue para os biodigestores, onde ocorre a estabilização através de processo biológico anaeróbico. Por fim, o lodo é desaguado (informação pessoal) ${ }^{3}$.

De forma geral, o lodo de Jundiaí apresenta-se mais digerido ou estabilizado que os outros, pois o seu tratamento é mais lento e, portanto, tende a apresentar parcela maior de substâncias orgânicas recalcitrantes como óleos, graxas e resinas. Já os lodos de Franca e Ribeirão Preto apresentam processamento mais rápido e isto faz com eles apresentem maior biomassa e matéria orgânica facilmente decomponível quando comparado ao lodo de Jundiaí. Além disso, o lodo de Jundiaí quando desaguado mostra-se neutro ( $\mathrm{pH} 7,0)$, sendo que os processos de nitrificação que ocorrem durante sua secagem por revolvimento mecânico o torna levemente ácido. Isto certamente acabaria ocorrendo com os lodos de Franca e Ribeirão Preto caso fossem depositados e submetidos à aeração (informação pessoal) ${ }^{4}$.

\footnotetext{
${ }^{2}$ OLIVEIRA, F.C. ETE - Jundiaí. Mensagem eletrônica recebida por marchese@cena.usp.br em 26 fev. 2007. ${ }^{3}$ FERREIRA, C.R. ETE - Ribeirão Preto. Mensagem eletrônica recebida por marchese@cena.usp.br em 15 mar. 2007.

${ }^{4}$ Fernando, C.R. ETE - Ribeirão Preto. Mensagem eletrônica recebida por marchese@,cena.usp.br em 15 mar. 2007.
} 
Tabela 1 - Propriedades físico-químicas dos solos estudados.

\begin{tabular}{|c|c|c|c|c|c|c|c|}
\hline Solo & pH & CTC $^{(1)}$ & M.O. ${ }^{(2)}$ & Areia & Silte & Argila & Classe textural \\
\hline & $\mathrm{CaCl}_{2}$ & mmolc dm ${ }^{-3}$ & $\mathrm{mg} \mathrm{dm}^{-3}$ & $\ldots \ldots \ldots . .$. & $\ldots \%$ & ................ & \\
\hline RQ & 4,1 & 39,6 & 20 & 90 & 2 & 8 & Areia \\
\hline $\mathrm{LVd}$ & 3,9 & 57,6 & 23 & 82 & 4 & 14 & Areia Barrenta \\
\hline LVdf & 4,9 & 102,6 & 45 & 43 & 9 & 48 & Argila \\
\hline PV & 5,3 & 243,9 & 48 & 31 & 27 & 42 & Argila \\
\hline
\end{tabular}

Tabela 2 - Caracterização química das amostras de lodos de esgoto.

\begin{tabular}{lcccccccccccc}
\hline \multicolumn{1}{c}{ Lodo } & $\mathbf{C}_{\text {total }}$ & \multicolumn{2}{c}{$\mathbf{C O D}^{(1)}$} & $\mathbf{p H}$ & $\mathbf{P}$ & $\mathbf{K}$ & $\mathbf{N a}$ & $\mathbf{C a}$ & $\mathbf{M g}$ & $\mathbf{N}$ & $\mathbf{C u}$ & $\mathbf{Z n}$ \\
\hline \multirow{3}{*}{ Ribeirão Preto } & $\mathrm{g} \mathrm{kg}^{-1}$ & $\mathrm{mg} \mathrm{L} \mathrm{L}^{-1}$ & $\mathrm{~g} \mathrm{~kg}^{-1}$ lodo & $\left(\mathrm{CaCl}_{2}\right)$ & $\ldots \ldots \ldots \ldots \ldots \ldots \ldots$ & $\mathrm{g} \mathrm{kg}^{-1} \ldots \ldots \ldots \ldots \ldots \ldots \ldots$. & $\ldots \ldots \mathrm{mg} \mathrm{kg}^{-1} \ldots$ \\
Franca & 404,7 & 289,2 & 17,3 & 8,1 & 19,4 & 1,1 & 0,9 & 23,8 & 4,9 & 22,2 & 685 & 1415 \\
Jundiaí & 279,5 & 79,2 & 4,7 & 7,9 & 19,4 & 1,3 & 1,7 & 9,4 & 1,9 & 11,1 & 245 & 1000 \\
& 364,9 & 25,7 & 1,5 & 5,1 & 7,7 & 1,5 & 2,1 & 20,6 & 5,6 & 15,7 & 669 & 1161 \\
\hline
\end{tabular}

(1) $\mathrm{COD}=$ carbono orgânico dissolvido 


\section{Sorção e dessorção nos solos tratados com lodo de esgoto (0 e 30 dias de incubação)}

O lodo de esgoto foi aplicado ao solo na dose correspondente a $20 \mathrm{t} \mathrm{ha}^{-1}$ (peso seco), sendo que a aplicação da ametrina foi realizada 0 e 30 após a adição das fontes de lodo.

Para a obtenção dos valores de $\mathrm{K}_{\mathrm{d}}$, alíquotas de $5 \mathrm{~mL}$ das soluções de ametrina, nas concentrações correspondentes a 4,4;9,0;19,2;39,2 e 79,8 e 4,3;9,4;19,7;40,2 e 81,5 mg i.a. $\mathrm{L}^{-1}$ para os períodos de 0 e 30 dias de incubação, respectivamente, foram adicionadas aos tubos de centrífuga $(35 \mathrm{~mL})$ contendo amostras de $5 \mathrm{~g}$ de solo ou solo+lodo, em duplicata. Para todas as soluções, a concentração radiativa foi de aproximadamente $0,17 \mathrm{kBq} \mathrm{mL} L^{-1}$. Os tubos foram agitados horizontalmente a $140 \mathrm{rpm}$ por $24 \mathrm{~h}$ e, posteriormente, centrifugados a $12100 \mathrm{~g}$ por $15 \mathrm{~min}$. Alíquotas de $1 \mathrm{~mL}$ dos sobrenadantes foram coletadas para determinar as concentrações de ametrina em equilíbrio na solução do solo $\left(\mathrm{C}_{\mathrm{e}}\right)$, por espectrometria de cintilação líquida (ECL). Em paralelo, duplicatas dos tubos com apenas $5 \mathrm{~mL}$ da solução de ametrina (sem o solo+lodo) foram agitadas e centrifugadas para eliminar a sorção do produto às paredes dos frascos.

A concentração de ametrina sorvida $(\mathrm{S})$ às partículas de solo foi calculada pela diferença entre a concentração inicial $\left(\mathrm{C}_{\mathrm{i}}\right)$ e a concentração de equilíbrio $\left(\mathrm{C}_{\mathrm{e}}\right)$, conforme a fórmula abaixo:

$$
S=\left(C_{i}-C_{e}\right) x V / M
$$

em que: $\quad \mathrm{S}=$ quantidade do pesticida sorvido

$\mathrm{C}_{\mathrm{i}}=$ concentração inicial do pesticida na solução

$\mathrm{C}_{\mathrm{e}}=$ concentração do pesticida na solução em equilíbrio com o solo

$\mathrm{V}=$ volume da solução do pesticida

$\mathrm{M}=$ massa de solo

Pela equação de Freündlich (GREEN; KARICKHOFF, 1990), o valor do coeficiente de 
sorção foi determinado:

$$
\mathrm{S}=\mathrm{K}_{\mathrm{f}} \times \mathrm{C}_{\mathrm{e}}^{\mathrm{N}}
$$

em que: $\quad \mathrm{S}=$ quantidade do pesticida sorvido

$\mathrm{K}_{\mathrm{f}}=$ coeficiente de sorção de Freündlich

$\mathrm{C}_{\mathrm{e}}=$ concentração do pesticida na solução em equilíbrio com o solo

$\mathrm{N}=$ coeficiente exponencial da equação

Os valores dos coeficientes de sorção aparentes $\left(\mathrm{K}_{d}{ }^{\mathrm{ap}}\right)$ obtidos individualmente para as diferentes concentrações iniciais de ametrina foram calculados de acordo com a equação abaixo, a partir da qual foi calculado o valor médio para as cinco concentrações testadas uma vez que $\mathrm{N} \neq 1$ :

$$
\mathrm{K}_{\mathrm{d}}^{\mathrm{ap}}=\mathrm{S} / \mathrm{C}_{\mathrm{e}}
$$

Como a sorção da maioria dos pesticidas é diretamente relacionada com o conteúdo de carbono orgânico do solo, o valor de $\mathrm{K}_{\mathrm{oc}}$ (constante de sorção normalizada em relação ao teor de carbono orgânico do solo) também foi calculado para a menor concentração testada do pesticida, correspondente a dose de campo recomendada (LAVORENTI; PRATA; REGITANO, 2003):

$$
\mathrm{K}_{\mathrm{oc}}=\left(\mathrm{K}_{\mathrm{d}} \times 100\right) / \mathrm{C}_{\mathrm{org}}
$$

em que: $\quad K_{\mathrm{oc}}=$ constante linear de sorção normalizada em relação ao teor de carbono orgânico do solo

$$
\mathrm{C}_{\text {org }}=\text { carbono orgânico do solo (\%) }
$$

Para o teste de dessorção, alíquota adicional de $1 \mathrm{~mL}$ dos sobrenadantes foi descartada, sendo reposta a alíquota de $2 \mathrm{~mL}$ da solução de $\mathrm{CaCl}_{2} 0,01$ mol L ${ }^{-1}$ a cada tubo de centrífuga. Posteriormente, os tubos foram agitados e centrifugados, nas mesmas condições anteriores, e 
alíquotas de $1 \mathrm{~mL}$ dos sobrenadantes foram retiradas para determinar as concentrações de ametrina dessorvidas em solução $\left(\mathrm{C}_{\mathrm{e}}^{\mathrm{des}}\right)$, por ECL. Este procedimento foi repetido mais quatro vezes.

O potencial de dessorção da ametrina foi calculado em relação a sua quantidade inicialmente sorvida, e não ao total aplicado:

$$
\mathrm{D}_{\%}=(\mathrm{D} / \mathrm{S}) \times 100
$$

em que: $\quad D_{\%}=$ porcentagem do pesticida dessorvido em relação a sua quantidade inicialmente sorvida

$\mathrm{D}=$ concentração do pesticida dessorvido.

\section{Análise estatística}

Foram feitos estudos de análise de variância e comparação de médias (Tukey, p < $0,05)$ para os valores de $K_{d}{ }_{[m e n o r]}\left(K_{d}{ }^{a p}\right.$ obtidos com a menor concentração da solução de ametrina), considerando-se os seguintes fatoriais: 4 solos (RQ, LVd, LVdf e PV) x 4 "lodos" (sem lodo, Ribeirão Preto, Franca e Jundiaí) x 2 períodos (0 e 30 dias de incubação com lodo). 


\subsection{RESULTADOS E DISCUSSÃO}

O potencial de sorção da ametrina variou de moderado a alto $\left(2,69<\mathrm{K}_{\mathrm{f}}<33,20\right)$ nos solos e lodos estudados, o que correspondeu de 61 a $99 \%$ da quantidade de ametrina aplicada (Tabela 3). As isotermas não apresentaram comportamento linear $(\mathrm{N} \neq 1)$, ou seja, $\mathrm{N}$ foi sempre menor que 0,92 (Tabela 3). Isto significa dizer que quanto maior a concentração de ametrina, menor o seu potencial de sorção aparente $\left(\mathrm{K}_{\mathrm{d}}{ }^{\mathrm{ap}}\right)$ e menor a sua porcentagem sorvida (S). Para o solo RQ, por exemplo, o valor de $\mathrm{K}_{\mathrm{d}}^{\text {ap }}$ diminuiu de 3,15 para $1,60 \mathrm{~L} \mathrm{~kg}^{-1}$ e o valor de S diminuiu de 76 para $61 \%$ com o aumento da concentração de ametrina de 4,4 para 79,8

mg L $\mathrm{L}^{-1}$ (Tabela 3). Acredita-se que com o aumento da concentração do produto ocorra saturação dos sítios de troca do solo, diminuindo o seu potencial de sorção. Ou seja, os sítios de ligação do solo com as moléculas de pesticida são limitados e à medida que a concentração do pesticida na solução do solo aumenta, esses sítios vão sendo saturados progressivamente, reduzindo o potencial de sorção do pesticida (WEBER; MILLER, 1989). Este tipo de comportamento exclui a partição hidrofóbica à superfície orgânica do solo como único mecanismo ditando o processo de sorção (CHIOU, 1989).

$\mathrm{Na}$ prática, o fato de $\mathrm{N}$ diferir entre os tratamentos impede o uso de $\mathrm{K}_{\mathrm{f}}$ para comparar os valores dos potenciais de sorção da ametrina, uma vez que eles apresentam dimensões diferentes (LAVORENTI; PRATA; REGITANO, 2003). Neste trabalho, apesar dos valores dos coeficientes de partição médio $\left(\mathrm{K}_{\mathrm{d}}{ }^{\mathrm{ap}}{ }_{\text {(médio) }}\right)$ terem sido calculados como médias dos valores obtidos nas diferentes concentrações, achou-se mais coerente comparar os valores de $\mathrm{K}_{\mathrm{d}}^{\text {ap }}$ obtidos para a menor concentração adotada $\left(\mathrm{K}_{d}{ }^{\mathrm{ap}}{ }_{[\mathrm{menor}]}\right)$, pois corresponde à dose máxima de ametrina recomendada a campo $\left(3,0 \mathrm{~kg}\right.$ i.a. $\left.\mathrm{ha}^{-1}\right)$. 
Tabela 3 - Parâmetros de sorção e dessorção obtidos nos diferentes tratamentos (incubação = 0 dias).

\begin{tabular}{|c|c|c|c|c|c|c|c|c|c|c|c|c|c|}
\hline \multirow[t]{2}{*}{ Tratamentos } & \multirow[t]{2}{*}{$\mathrm{C}_{\text {org. }}$} & \multirow[t]{2}{*}{$\mathbf{p H}$} & \multirow[t]{2}{*}{$\mathbf{K}_{\mathbf{f}}$} & \multirow[t]{2}{*}{$\mathbf{N}$} & \multirow[t]{2}{*}{$\mathbf{r}^{2}$} & \multirow[t]{2}{*}{$K_{d}{ }^{\text {ap }}{ }_{\text {(médio) }}{ }^{(1)}$} & \multicolumn{2}{|c|}{$\mathbf{K}_{\mathbf{d}}{ }^{\mathrm{ap}}$} & \multicolumn{2}{|c|}{$\mathrm{S}$} & \multicolumn{2}{|c|}{$\mathbf{D}_{\%}$} & \multirow[t]{2}{*}{$\mathbf{K}_{\mathbf{o c}[\text { menor }]}$} \\
\hline & & & & & & & {$[\text { menor }]^{(3)}$} & 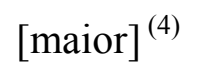 & [menor] & [maior] & [menor] & [maior] & \\
\hline & $\mathrm{g} \mathrm{kg}^{-1}$ & & & & & ....................... &.. $\mathrm{L} \mathrm{kg}^{-1} \ldots \ldots$ & ................... &..$\%$ do $\mathrm{a}$ & licado .. &..$\%$ do $\mathrm{s}$ & orvido .. & $. . \mathrm{L} \mathrm{kg}^{-1} .$. \\
\hline RQ & 11,6 & 4,1 & 3,13 & 0,81 & 0,99 & 2,31 & $3, \mathbf{1 5} \mathbf{d}^{(2)}$ & 1,60 & 76 & 61 & 30 & 42 & 199,1 \\
\hline RQ+Rib. Preto & 18,1 & 6,6 & 2,69 & 0,92 & 0,99 & 2,34 & $2,68 \mathrm{~d}$ & 2,00 & 72 & 65 & 34 & 39 & 129,4 \\
\hline RQ+Franca & 16,0 & 5,9 & 3,29 & 0,84 & 0,99 & 2,54 & $3,34 \mathrm{~d}$ & 1,90 & 76 & 64 & 30 & 36 & 158,5 \\
\hline RQ+Jundiaí & 17,4 & 4,7 & 4,25 & 0,83 & 0,99 & 3,38 & $4,43 d$ & 2,59 & 81 & 72 & 25 & 30 & 193,9 \\
\hline $\mathrm{LVd}$ & 13,3 & 3,9 & 4,01 & 0,70 & 0,99 & 2,63 & $4,76 \mathrm{~d}$ & 1,59 & 83 & 61 & 18 & 39 & 197,7 \\
\hline LVd+Rib. Preto & 19,8 & 6,1 & 3,02 & 0,92 & 0,99 & 2,64 & $3,17 \mathrm{~d}$ & 2,34 & 75 & 69 & 33 & 34 & 133,5 \\
\hline LVd+Franca & 17,7 & 5,6 & 5,34 & 0,76 & 0,99 & 3,09 & $4,73 d$ & 2,06 & 82 & 66 & 23 & 36 & 174,5 \\
\hline LVd+Jundiaí & 19,1 & 4,2 & 4,23 & 0,78 & 0,99 & 4,03 & $6,28 \mathrm{~d}$ & 2,72 & 86 & 72 & 18 & 29 & 210,8 \\
\hline LVdf & 26,2 & 4,9 & 5,45 & 0,75 & 0,99 & 4,02 & $6,48 \mathrm{~d}$ & 2,52 & 86 & 70 & 20 & 32 & 153,4 \\
\hline LVdf+Rib. Preto & 32,9 & 6,2 & 4,19 & 0,86 & 0,99 & 3,43 & $4,30 \mathrm{~d}$ & 2,70 & 79 & 71 & 26 & 32 & 104,3 \\
\hline LVdf+Franca & 30,7 & 5,8 & 4,85 & 0,83 & 0,99 & 3,86 & $5,41 \mathrm{~d}$ & 2,94 & 83 & 72 & 21 & 25 & 125,9 \\
\hline LVdf + Jundiaí & 19,1 & 5,3 & 5,60 & 0,79 & 0,99 & 4,39 & $6,28 \mathrm{~d}$ & 3,05 & 85 & 74 & 17 & 26 & 136,5 \\
\hline PV & 27,8 & 5,3 & 32,34 & 0,66 & 0,99 & 47,76 & 85,71 a & 20,19 & 99 & 95 & 2 & 4 & 1718,0 \\
\hline PV+Rib. Preto & 34,5 & 6,2 & 14,64 & 0,76 & 0,99 & 13,97 & $22,38 \mathrm{c}$ & 9,03 & 95 & 89 & 6 & 11 & 404,9 \\
\hline PV+Franca & 32,3 & 6,1 & 24,07 & 0,70 & 0,99 & 28,57 & 50,08 b & 14,14 & 98 & 93 & 3 & 6 & 885,3 \\
\hline PV+Jundiaí & 33,8 & 5,6 & 33,20 & 0,70 & 0,99 & 45,03 & 81,79 a & 22,98 & 99 & 95 & 1 & 3 & 1332,6 \\
\hline
\end{tabular}

\footnotetext{
(1) $\mathrm{K}_{\mathrm{d}}^{\mathrm{ap}}$ (médio) $=$ média das cinco concentrações utilizadas

(2) Para cada tratamento, letras iguais na mesma coluna não diferem entre si pelo teste de Tukey $(\mathrm{p}<0,05)$

(3) $[$ menor $]=$ menor concentração utilizada
}

(4) $[$ maior $]=$ maior concentração utilizada 
Os resultados dos estudos de análise de variância e comparação de médias (Tukey, p < $0,05)$ para os fatoriais estudados mostraram que houve efeito do tipo de solo, da fonte de lodo, do período de incubação e da interação solo-lodo no potencial de sorção da ametrina, tendo-se o valor de $K_{d}{ }^{\text {p }}{ }_{\text {[menor] }}$ como variável analisada (Tabelas 3 e 4). Inicialmente, pode-se observar que, em média, o potencial de sorção da ametrina no solo PV $>>$ LVdf $>$ LVd $>$ RQ, embora nem todas essas diferenças tenham sido estatisticamente significativas (vide letras, Tabelas 3 e 4). Maiores potenciais de sorção para os solos PV e LVdf seriam esperados, uma vez que estes solos apresentaram maiores teores de M.O. e argila, embora apresentassem maiores valores de $\mathrm{pH}-\mathrm{CaCl}_{2}$. Sabe-se que a ametrina apresenta caráter de base fraca $\left(\mathrm{pK}_{\mathrm{a}}=4,1\right)$ e, como tal, pode co-existir tanto na forma protonada (catiônica) ou neutra (apolar), dependendo das reações de equilíbrio com o pH do meio (KOSKINEN; HARPER, 1990). Isto quer dizer que quanto maior o valor do $\mathrm{pH}$ da solução do solo, maior a porcentagem de moléculas de ametrina na forma neutra e, consequentemente, menor o seu potencial de sorção. A fração coloidal do solo normalmente apresenta balanço de cargas elétricas negativo, apresentado assim, maior interação, por forças eletrostáticas, com as moléculas catiônicas do que com as neutras (BRICEÑO; PALMA; DURÁN, 2007). Celis, Barriuso e Houot (1998) já haviam observado que a sorção da atrazina, molécula pertencente à mesma classe que a ametrina, é inversamente relacionada ao pH da solução do solo.

Tabela 4 - Análise de variância e comparação de médias para os valores de $\mathrm{K}_{\mathrm{d}}{ }^{\mathrm{ap}}{ }_{\text {[menor] }}$.

\begin{tabular}{|c|c|c|c|c|c|}
\hline Solo & Média & Lodo & Média & Período & Média \\
\hline RQ & $3,27 \mathrm{c}^{(1)}$ & Sem lodo & $25,10 \mathrm{a}$ & 0 dias & $18,47 \mathrm{~b}$ \\
\hline LVd & $4,56 \mathrm{bc}$ & Rib. Preto & $9,17 \mathrm{c}$ & 30 dias & $20,24 \mathrm{a}$ \\
\hline LVdf & $5,90 \mathrm{~b}$ & Franca & $16,24 \mathrm{~b}$ & & \\
\hline PV & $63,69 \mathrm{a}$ & Jundiaí & $26,91 \mathrm{a}$ & & \\
\hline
\end{tabular}


O potencial de sorção muito maior no PV em relação aos outros solos e, principalmente, ao LVdf deve-se à maior reatividade de sua fração argila, uma vez que ambos os solos apresentam praticamente os mesmos teores de M.O. e argila (Tabela 1). O solo PV é o único que apresenta argilas do tipo 2:1 (Tabela 1) e, conseqüentemente, maior valor de CTC, o que pode ter contribuído com sítios mais efetivos na sorção da ametrina (GILCHRIST et al, 1993; MARTIN-SANCHEZ et al., 2006; POLATI et al, 2006). De acordo com Abreu Jr, Muraoka e Oliveira (2001), as cargas negativas responsáveis pelo aumento da CTC do solo são decorrentes da desprotonação dos grupos funcionais encontrados na superfície da matéria orgânica do solo e dos minerais de argila, além dos processos de substituição isomórfica, que dependem do $\mathrm{pH}$ do solo. Wehtje, Walker e Shaw (2000) afirmaram que a CTC pode influenciar a retenção de produtos químicos; enquanto que Green e Karickhoff (1990) já haviam observado que os minerais de argila podem assumir papel importante na sorção de algumas moléculas orgânicas hidrofóbicas, como os pesticidas, principalmente quando o conteúdo de $\mathrm{C}_{\text {org }}$ é baixo. A este respeito, Li, Xung e Torello (2005), afirmaram que a contribuição dos minerais de argila na sorção de compostos nitroaromáticos, como a ametrina, pode se igualar ou até mesmo superar a contribuição da matéria orgânica do solo.

Por outro lado, os menores potenciais de sorção da ametrina nos solos LVd e RQ, subseqüentemente, seriam esperados uma vez que estes solos apresentaram menores teores de M.O. e maiores teores de areia ( $\geq 82 \%$ ) (Tabela 1$)$.

As fontes de lodo também influenciaram diretamente o potencial de sorção da ametrina. De forma geral, pode-se dizer que o lodo de Jundiaí não afetou o comportamento sortivo da ametrina em relação ao tratamento testemunha (solo sem o lodo), enquanto que os lodos de Franca e, principalmente, o de Ribeirão Preto tenderam a diminuir o potencial de sorção da ametrina nos solos estudados $($ Testemunha $=$ Jundiaí $>$ Franca $>$ Ribeirão Preto, Tabela 4). Provavelmente, este comportamento deve-se ao fato dos lodos de Ribeirão Preto e Franca 
apresentarem elevados valores de $\mathrm{pH}$ e maiores frações de COD (Tabela 2). O COD pode se associar às moléculas de ametrina dissolvidas na solução do solo, pelo mecanismo de cosolvência aumentando a sua solubilidade, ou competir com o pesticida pelos sítios de sorção do solo; enquanto que valores elevados de $\mathrm{pH}$ favorecem o predomínio de moléculas neutras (ao invés das catiônicas), sendo que ambas as propriedades contribuem para a redução do potencial de sorção da ametrina. Lee, Farmer e Aochi (1990); Celis, Barriuso e Houot (1998) e Ilani, Schulz e Chefetz (2005) observaram que a associação do COD aos compostos orgânicos, entre eles os pesticidas, em suspensão é o principal processo responsável pela redução do potencial de sorção de moléculas químicas hidrofóbicas aos solos e sedimentos. Os mesmos autores observaram que é necessária alta concentração de COD $\left(>150 \mathrm{mg} \mathrm{L}^{-1}\right)$ para reduzir significativamente o potencial de sorção de triazinas no solo. Este valor só foi encontrado para o lodo de Ribeirão, após cálculo assumindo a dose de $20 \mathrm{t} \mathrm{ha}^{-1}$ e o volume de aplicação de $5 \mathrm{~mL}$ da solução de ametrina em $5 \mathrm{~g}$ de solo (Tabela 2). Provavelmente, esta maior quantidade de COD e o maior valor de pH deve-se ao menor tempo de estabilização no tratamento do lodo de Ribeirão, resultando num lodo menos recalcitrante.

$\mathrm{Na}$ literatura adota-se que pesticidas com valores de $\mathrm{K}_{\mathrm{d}}<5 \mathrm{~L} \mathrm{~kg}^{-1}$ (ou $\mathrm{K}_{\mathrm{oc}}<300-500 \mathrm{~L}$ $\mathrm{kg}^{-1}$ ) e meia-vida $\left(\mathrm{t}_{1 / 2}\right)>21$ dias apresentam potencial de lixiviação (COHEN et al., 1984 apud WELLS; WALDMAN; BEHL, 1995, p.265) ${ }^{5}$. Isto demonstra que a ametrina poderá lixiviar na maioria dos solos mesmo após a aplicação das fontes de lodo, exceto no solo PV. Problemas associados à lixiviação da ametrina poderão tornar-se mais críticos nos solos arenosos (LVd e RQ) tratados com o lodo de Ribeirão Preto, com menores potenciais de sorção (Tabela 3). Apesar das fontes de lodo terem influenciado de forma significativa o potencial de sorção da ametrina, as suas adições ao solo pouco alteraram a classificação do

\footnotetext{
${ }^{5}$ COHEN, S.Z.; CREEGER, S.M.; CARSEL, R.F.; ENFIELD, C.G. Potencial pesticide contamination of groundwater from agricultural uses. In: Treatment and disposal of pesticide wastes, KRUEGAR, R.F.; SEIBER, J.N. Washington: American Chemical Society, 1984.
} 
seu potencial de lixiviação. Em outras palavras, o potencial de lixiviação da ametrina variou sempre entre moderado $\left(2<\mathrm{K}_{\mathrm{d}}<5 \mathrm{~L} \mathrm{~kg}^{-1}\right)$ e alto $\left(\mathrm{K}_{\mathrm{d}}>5 \mathrm{~L} \mathrm{~kg}^{-1}\right)$, mesmo após a adição das diferentes fontes de lodo (Tabela 3). Além disso, quando a interação solo x lodo foi desdobrada, pode-se observar que as fontes de lodo afetaram significativamente apenas a sorção da ametrina no solo PV. Todos os outros tratamentos foram estatisticamente iguais (Tabela 3).

As principais características dos lodos de esgoto que podem influenciar o potencial de sorção dos pesticidas aos solos são: o conteúdo de $\mathrm{C}_{\text {org }}$ (sólido ou dissolvido), a força iônica, a composição iônica e o valor de pH (SEOL; LEE, 2000). Portanto, traçou-se a curva de correlação entre os valores de $\mathrm{K}_{\mathrm{oc}}$ e os de $\mathrm{pH}$ da solução do solo para avaliar os efeitos do teor de matéria orgânica do solo, expressa pelo teor de $\mathrm{C}_{\mathrm{org}}$, e da concentração de hidrogênios $(\mathrm{pH})$ na sorção da ametrina (Figura 2). $\mathrm{K}_{\mathrm{oc}}$ representa o coeficiente de sorção de um pesticida normalizado à propriedade do solo que mais influencia o seu potencial de sorção, o conteúdo de $\mathrm{C}_{\text {org }}$ (LAVORENTI; PRATA; REGITANO, 2003).

A estreita correlação entre as variáveis estudadas mostra que a sorção da ametrina depende diretamente do teor de matéria orgânica da amostra, expresso pelo carbono orgânico, e do $\mathrm{pH}$ da solução do solo (Figura 2). Mais uma vez, fica claro que quanto menor o $\mathrm{pH}$ da solução do solo e maior o teor de matéria orgânica da amostra, maior a sorção da ametrina (Tabela 3 e Figura 2). De forma geral, a adição das diferentes fontes de lodo aumentou o teor de matéria orgânica e o de COD no solo, os quais agem antagonicamente no potencial de sorção dos pesticidas. Além disso, as fontes de lodo também contribuíram para o aumento do pH da solução do solo, que contribui para a redução no potencial de sorção (Tabela 4). Naramabuye e Haynes (2006) já haviam observado que o pH dos solos aumenta quando acrescidos de diferentes materiais orgânicos, dentre eles, o lodo de esgoto. Portanto, o balanço entre a influência destas propriedades irá ditar se o efeito da adição de uma determinada fonte 
de lodo na sorção da ametrina será positivo ou negativo. Por outro lado, o comportamento diferencial do solo PV (Figura 2), independentemente da fonte de lodo adicionada, evidencia que o teor de $\mathrm{C}_{\mathrm{org}}$, de $\mathrm{COD}$ e o pH da solução do solo não são as únicas propriedades do solo influenciando o potencial de sorção da ametrina. Para o PV, a presença de uma grande fração de argilo-minerais do tipo 2:1 deve ter contribuído para a existência de sítios de trocas reativos para a sorção da ametrina. O fato de este solo ter apresentado maior valor de CTC ratifica esta observação.

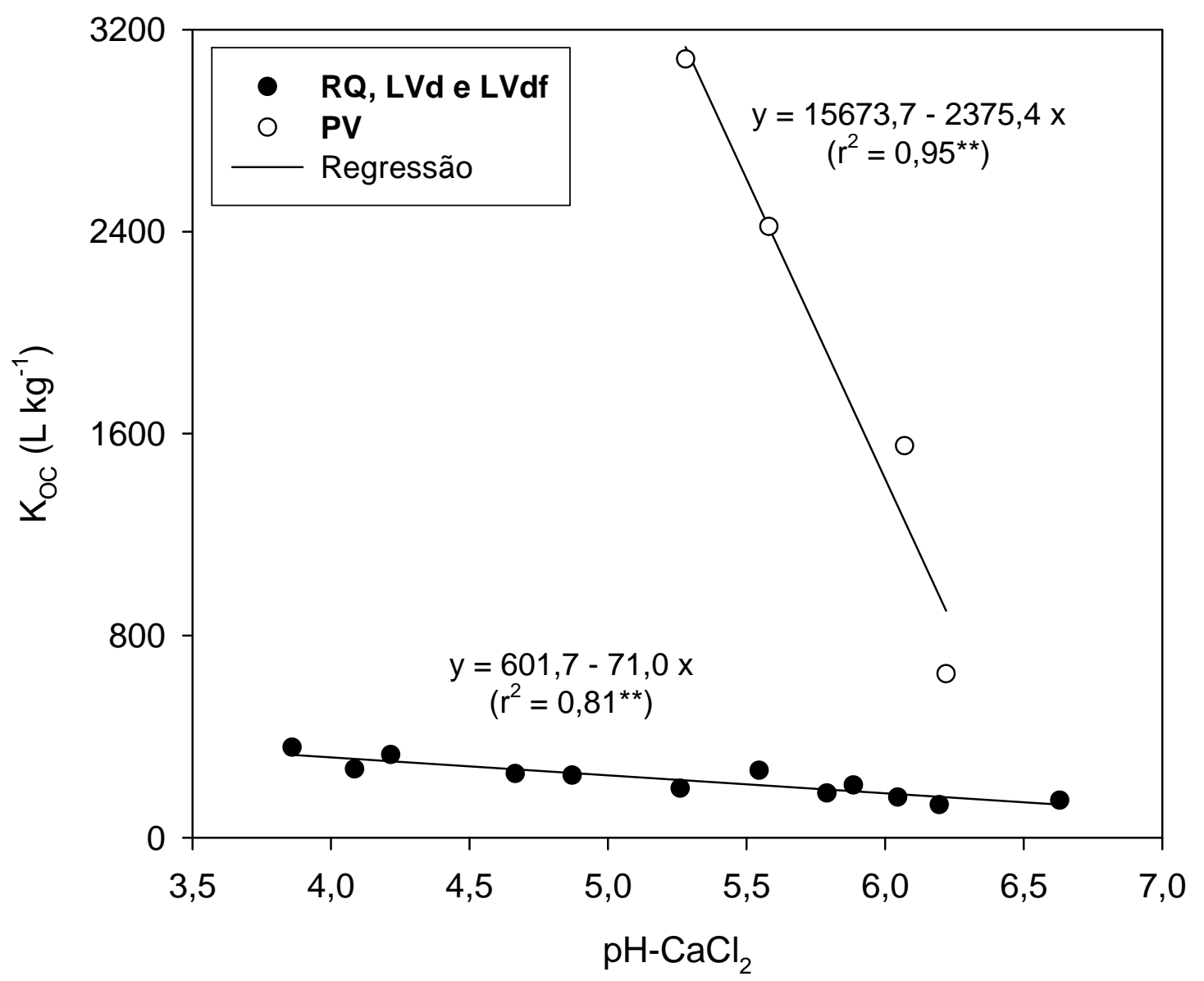

Figura 2. Curva de correlação entre os valores de $\mathrm{K}_{\mathrm{oc}}$ e os de $\mathrm{pH}$ da solução do solo. 
Nos solos mais argilosos, PV e LVdf, todas as fontes de lodo tenderam a reduzir o potencial de sorção da ametrina em relação ao solo original (Tabela 4). Estes solos apresentaram maiores teores matéria orgânica, o que deve ter mascarado, ou melhor, tamponado o efeito da adição de material orgânico sólido com a aplicação dos lodos, prevalecendo os efeitos dos aumentos nos valores de $\mathrm{pH}$ e de COD, que tendem a diminuir o potencial de sorção da ametrina. Nos solos mais arenosos, RQ e LVd, o mesmo tipo de comportamento foi apenas observado com o lodo de Ribeirão, provavelmente devido ao seu alto teor de COD e elevado $\mathrm{pH}$. Contudo, o lodo de Jundiaí tendeu a aumentar o potencial de sorção nesses solos. Neste caso, os efeitos da adição do material orgânico sólido, mais recalcitrante devido ao seu maior tempo de estabilização no preparo, deve ter sobrepujado os efeitos da adição paralela de COD e da elevação do pH, uma vez que solos mais arenosos normalmente apresentam menores teores de matéria orgânica e argila e, consequentemente, menor capacidade tampão. O fato do lodo de Jundiaí apresentar menor teor de COD, menor valor de $\mathrm{pH}$ e quantidade considerável de carbono orgânico total (Tabela 2) ratifica o acima observado. Celis, Barriuso e Houot (1998) já haviam notado que a adição de pequenas quantidades de lodo de esgoto em solos pobres em matéria orgânica poderia provocar aumento no potencial de sorção de pesticidas. Finalizando, o lodo de Franca pouco influenciou o potencial de sorção da ametrina nestes solos mais arenosos.

O processo de dessorção é crucial no comportamento de pesticidas no ambiente, pois controla a sua disponibilidade na solução no solo após a aplicação, além de refletir o grau de interação do produto com as partículas do solo. Neste contexto, a histerese reflete a diferença entre as declividades das curvas de sorção e dessorção, o que normalmente resulta da ligação do pesticida à matriz do solo, principalmente à matéria orgânica e aos minerais de argila. Para todos os tratamentos, uma pequena quantidade da ametrina aplicada $(<25,3 \%$ do aplidado; dados não apresentados) ou daquela retida durante o processo de sorção ( $<41,8$ \% do sorvido, 
Tabela 3) foi dessorvida, enfatizando que parte da ametrina fica retida no solo de forma pouco disponível (ou mesmo, não-disponível), podendo até formar resíduos ligados ao solo. Isto ratifica que a ametrina apresenta interações mais específicas com as partículas sólidas do solo. Além disso, pode-se notar que o PV apresentou maior histerese (resistência à dessorção), enquanto que o RQ apresentou menor histerese entre os solos estudados (Figura 3). Isto seria esperado uma vez que o solo PV apresenta maior potencial de sorção, sugerindo interações específicas com os minerais de argila, conforme mencionado anteriormente. Pode-se também observar maior dessorção da ametrina no tratamento com o lodo de Ribeirão, conforme seria esperado pelas suas q COD e pH. De forma geral, o aumento no potencial de dessorção de pesticidas ao solo pelo acréscimo de COD tem sido atribuído à competição entre o pesticida e o COD pelos sítios de sorção do solo (CELIS, BARRIUSO, HOUOT; 1998; BUSINELLI, 1997).

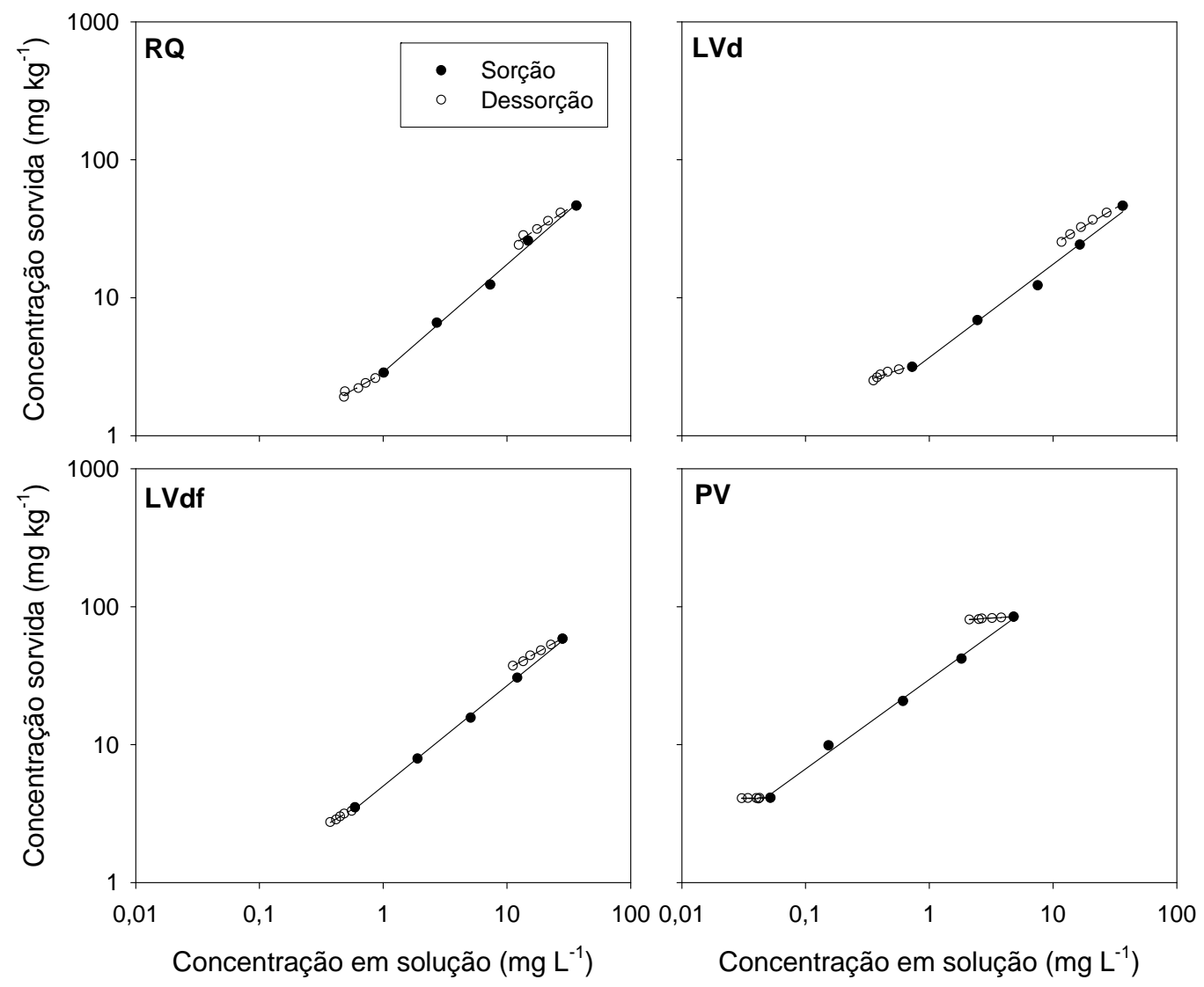

Figura 3. Curvas de sorção e dessorção da ametrina nos solos estudados. 
Os resultados dos coeficientes de sorção obtidos após 30 dias de incubação dos solos com os lodos mostram pequenas alterações quando comparados com os valores obtidos com zero dia de incubação (Tabela 5), embora essa diferença tenha sido, em média, estatisticamente significativa (Tabela 4). Portanto, sob o ponto de vista de comportamento ambiental, os diferentes tratamentos comportaram-se da mesma maneira nos dois períodos de incubação. Talvez coubesse questionar aqui se a metodologia adotada não estaria mascarando a ordem de grandeza dos resultados obtidos, uma vez que artifícios como o emprego de amostras deformadas de solo, agitação e desproporcional relação solo:solução poderiam estar influenciando o real potencial de sorção da ametrina nos tratamentos estudados em condições de campo.

Tabela 5 - Parâmetros de sorção e dessorção obtidos nos diferentes tratamentos (incubação = 30 dias).

\begin{tabular}{|c|c|c|c|c|c|c|c|}
\hline \multirow[t]{2}{*}{ Tratamentos } & \multirow[t]{2}{*}{$K_{d}^{a p}{ }_{\text {(médio) }}{ }^{(1)}$} & \multicolumn{2}{|c|}{$\mathbf{K}_{\mathbf{d}}^{\text {ap }}$} & \multicolumn{2}{|c|}{$\mathbf{S}$} & \multicolumn{2}{|c|}{$\mathbf{D}_{\%}$} \\
\hline & & [menor] & $\overline{[\text { maior }]}$ & [menor] & [maior] & [menor] & [maior] \\
\hline & \multicolumn{3}{|c|}{$\mathrm{L} \mathrm{kg}^{-1} \ldots . .}$. & \multicolumn{2}{|c|}{.. \% do aplicado .. } & \multicolumn{2}{|c|}{.. \% do sorvido .. } \\
\hline RQ & 2,31 & 3,15 & 1,60 & 76 & 61 & 30 & 42 \\
\hline RQ+Rib. Preto & 2,34 & 2,78 & 1,95 & 73 & 66 & 37 & 39 \\
\hline RQ+Franca & 2,04 & 2,57 & 1,63 & 72 & 62 & 35 & 40 \\
\hline RQ+Jundiaí & 3,05 & 4,05 & 2,37 & 80 & 70 & 25 & 30 \\
\hline $\mathrm{LVd}$ & 2,63 & 4,76 & 1,59 & 83 & 61 & 18 & 39 \\
\hline LVd+Rib. Preto & 2,93 & 3,84 & 2,16 & 79 & 68 & 27 & 37 \\
\hline LVd+Franca & 2,73 & 4,05 & 1,88 & 80 & 65 & 24 & 34 \\
\hline LVd+Jundiaí & 3,82 & 4,86 & 2,78 & 83 & 73 & 21 & 27 \\
\hline LVdf & 4,02 & 6,48 & 2,52 & 86 & 70 & 20 & 32 \\
\hline LVdf+Rib. Preto & 3,85 & 4,98 & 2,99 & 83 & 74 & 20 & 27 \\
\hline LVdf+Franca & 3,84 & 5,84 & 2,62 & 85 & 72 & 19 & 27 \\
\hline LVdf+Jundiaí & 4,74 & 7,25 & 2,94 & 87 & 74 & 16 & 25 \\
\hline PV & 47,76 & 85,71 & 20,19 & 99 & 95 & 2 & 4 \\
\hline PV+Rib. Preto & 17,00 & 28,89 & 8,62 & 96 & 89 & 5 & 9 \\
\hline PV+Franca & 29,12 & 53,83 & 12,77 & 98 & 92 & 3 & 5 \\
\hline PV+Jundiaí & 54,51 & 99,99 & 23,90 & 99 & 96 & 1 & 3 \\
\hline
\end{tabular}




\subsection{CONCLUSÕES}

Solos argilosos, com maior teor de matéria orgânica e argilas do tipo 2:1 apresentam muito maior potencial de sorção da ametrina, como é o caso do PV, enquanto que solos arenosos com baixos teores de matéria orgânica apresentam moderado potencial de sorção.

A adição do lodo de esgoto aos solos provocou pequenas alterações no potencial de sorção da ametrina. No entanto, essas pequenas alterações permitem concluir que o potencial de sorção da ametrina ao solo é função, principalmente, dos teores de $\mathrm{C}_{\mathrm{org}}$ e COD e do $\mathrm{pH}$ da fonte de lodo adicionada. Lodos menos estabilizados, com biomassa e material orgânico menos recalcitrante, como é o caso do lodo de Ribeirão Preto e, consequentemente, maiores valores de COD e pH tendem a diminuir o potencial de sorção da ametrina.

A adição de lodos mais recalcitrantes, como o de Jundiaí, em solos arenosos representou a única situação potencialmente problemática no que diz respeito à diminuição da eficácia agronômica da ametrina, pois neste cenário ocorreu aumento do seu potencial de sorção, o que diminuiria sua disponibilidade na solução do solo. Paralelamente, a aplicação deste lodo nestes tipos de solo deve contribuir para a redução do seu potencial de lixiviação para fontes de águas subterrâneas.

Resumindo, é preciso avaliar todas as variáveis da molécula, do solo e do lodo, além dos fatores climáticos e de manejo, quando se deseja proceder à aplicação do lodo de esgoto em áreas agrícolas, a fim de minimizar os impactos e riscos de contaminação ambiental pelo uso de pesticidas na área, bem como evitar a redução na sua eficácia agronômica. Portanto, mais estudos ainda são necessários, especialmente em situações em que haja aplicações seqüenciais do resíduo como fertilizante orgânico. 


\section{LIXIVIAÇÃO DO HERBICIDA AMETRINA EM SOLOS CANAVIEIROS TRATADOS COM LODO DE ESGOTO}

\section{Resumo}

A aplicação de diferentes fontes de matéria orgânica ao solo, como o lodo de esgoto, vem aumentando o interesse sobre a influência desse material no comportamento e na eficácia dos pesticidas. O presente trabalho teve como objetivo avaliar o impacto da adição de duas fontes de lodo de esgoto (Ribeirão Preto e Jundiaí) sobre o processo de lixiviação da ametrina em dois tipos de solo (Neossolo Quartzarênico Órtico Típico (RQ) e Latossolo Vermelho Distroférrico (LVdf) utilizados para o cultivo da cultura da cana-de-açúcar. O método utilizado foi o de lixiviação em colunas de solo (diâmetro $=5 \mathrm{~cm}$ e comprimento $=30 \mathrm{~cm}$ ), utilizando-se três repetições para cada tratamento, sobre as quais foi simulada chuva de 200 mm uniformemente distribuídas durante 48 h, após a aplicação da solução de ${ }^{14} \mathrm{C}$-ametrina na dose de 3,0 kg i.a. ha ${ }^{-1}$. Os resultados mostraram que a ametrina apresentou baixo potencial de lixiviação $(<1 \%$ da quantidade aplicada) em todos os tratamentos, os quais não apresentaram diferenças entre si, sendo que a grande maioria do pesticida $(>95 \%$ da quantidade aplicada) ficou retida na camada de 0-10 $\mathrm{cm}$ de profundidade da coluna de solo. Isto implica dizer que a ametrina apresenta baixo potencial de contaminar águas subterrâneas, mesmo em solos arenosos, como RQ (90\% de areia).

Palavras-chave: percolação, transporte, triazinas, biossólidos, águas subterrâneas 


\begin{abstract}
The application of different sources of organic matter to the soil, as the sewage sludge, has enhanced the interest about the influence of this material on the fate and efficacy of pesticides. The present work had as objective to evaluate the impact of the addition of two sewage sludge sources (Ribeirão Preto e Jundiaí) on the leaching potential of ametryne in two soils (Neossolo Quartzarênico Órtico Típico (RQ) e Latossolo Vermelho Distroférrico (LVdf) used for sugarcane cultivation. The adopted method was soil leaching columns (diameter $=5$ $\mathrm{cm}$ and depth $=30 \mathrm{~cm}$ ), in triplicates, over which a $200 \mathrm{~mm}$ rainfall evenly distributed during $48 \mathrm{~h}$ was simulated just after ametryne application at the rate of $3.0 \mathrm{~kg}$ a.i. ha ${ }^{-1}$. The results emphasized that ametryne presented low leaching potential in all treatments $(<1 \%$ of the applied amount), which were not different among themselves, and that its majority ( $>95 \%$ of the applied amount) was found at 0 to $10 \mathrm{~cm}$ soil depth in the column. It implies that ametryne has low potential to contaminate groundwater even in sandy soils, such as the RQ (90\% sand).
\end{abstract}

Key words: percolation, transport, triazines, biosolids, ground water 


\subsection{INTRODUÇÃO}

A maior parte dos pesticidas utilizados na agricultura acaba atingindo o solo e as águas, principalmente pela deriva na aplicação, lixiviação, erosão com escoamento superficial, forma de aplicação para o controle de ervas daninhas, lavagem das folhas tratadas, aplicação direta em águas para controle de vetores de doenças e outros, descarte de resíduos de embalagens vazias, lavagens de equipamentos de aplicação e efluentes de indústrias de pesticidas (DE LUNA; DE SALES; DA SILVA, 2007). Esta situação torna-se cada vez mais preocupante, pois além de seus efeitos toxicológicos, os pesticidas interferem na dinâmica dos ecossistemas, como nos processos de quebra da matéria orgânica e de respiração do solo, no ciclo de nutrientes e na eutrofização de águas, entre outros. De acordo com De Luna, De Sales e Da Silva (2007), a falta de informação sobre o comportamento dos pesticidas no ambiente parece ser a grande incógnita. Para Fernandes et al. (2006), o problema quanto à utilização de pesticidas relaciona-se à dificuldade em aplicá-los especificamente no organismo alvo, limitando sua distribuição no meio ambiente, pois os pesticidas são também potencialmente danosos aos organismos não alvos (BECKMANN, 2007).

Neste cenário, vários países têm desenvolvido pesquisas para avaliar a presença e a toxicidade de pesticidas em águas superficiais e subterrâneas, pois entre os ecossistemas existentes, os ambientes aquáticos correspondem ao destino final de grande variedade e quantidade de poluentes (BRONDI; LANÇAS, 2004). Através de vários trabalhos, tem sido possível confirmar a presença de herbicidas, inseticidas e fungicidas em corpos d'água, destacando-se os grupos clorados, fenoxiacéticos, triazinas, triazinonas, piridinocarboxílicos e benzimedazole. Miles e Pfeuffer (1997) detectaram que a ametrina, a atrazina, o bromacil, a simazina e o norflurazon foram os pesticidas detectados em maior freqüência em amostras de água de 27 estações no sul da Flórida (EUA). Adicionalmente, os herbicidas têm sido mais 
frequentemente estudados devido ao fato da nova geração de pesticidas ser mais solúvel em água, aumentando o potencial de lixiviação dos mesmos (MULLER et al., 2002).

O destino dos pesticidas no meio ambiente é governado por processos de transporte e transformação. Os processos de transporte mais estudados são os de escoamento superficial, volatilização e lixiviação. Os processos de transformação incluem a degradação por processos químicos, fotoquímicos ou biológicos (FERNANDES et al., 2006). Neste contexto, os processos de sorção e dessorção, responsáveis pela transferência do pesticida da fase líquida para a fase sólida do solo e vice-versa, são fundamentais, uma vez que eles ditam a disponibilidade do pesticida na solução do solo, fração esta sujeita aos processos de transporte e transformação. Vários trabalhos na literatura mostram, através de estudos realizados em laboratório, a existência de relação inversa entre os processos de sorção e lixiviação de pesticidas no solo (FERNANDES et al., 2006). Em outras palavras, quanto maior o potencial de sorção do pesticida, menor o seu potencial de lixiviação.

No processo de lixiviação, as propriedades físico-químicas dos compostos utilizados e as propriedades do solo desempenham papel decisivo (WORRALL et al., 2001). Neste sentido, geralmente o potencial de lixiviação de um pesticida é maximizado quando o mesmo possui alta solubilidade ( $>30 \mathrm{ppm})$, baixo potencial de sorção $\left(\mathrm{K}_{\mathrm{d}}<5 \mathrm{~L} \mathrm{~kg}^{-1}\right.$ ou $\mathrm{K}_{\mathrm{oc}}<300$ $500 \mathrm{~g} \mathrm{~g}^{-1}$ de carbono), alta persistência ( $\mathrm{t}_{1 / 2}>2$ a 3 semanas) e é aplicado em solos arenosos com baixo conteúdo de matéria orgânica (FUTCH; SINGH, 1999; WELLS; WALDMAN; BEHL, 1995).

Recentemente, a influência da adição de matéria orgânica ao solo sobre o comportamento de pesticidas tem sido objeto de estudo. Através da adição de resíduos orgânicos (por exemplo, lodo de esgoto) ao solo, adicionam-se grandes quantidades de matéria orgânica, o que pode afetar os processos de sorção/dessorção e lixiviação de pesticidas no solo. Em alguns casos, esta prática pode reduzir a contaminação de águas 
superficiais e subterrâneas (GRABER et al., 2001; SINGH, 2003; SI et al., 2006; BRICEÑO; PALMA; DURÁN, 2007).

A aplicação de lodo de esgoto, rico em matéria orgânica, em áreas agrícolas tem se tornado prática cada vez mais comum em vários países, inclusive no Brasil, pois propicia aumento da fertilidade do solo, além de outras melhorias em suas propriedades físicoquímicas, tais como aumento da porosidade, aumento da capacidade de troca de cátions, manutenção do pH do solo e redução de perdas por erosão (DE MELO et al, 2004; GASCÓ; LOBO; GUERRERO, 2005). Até o momento, a dose recomendada de aplicação do lodo de esgoto tem sido calculada com base nos seus teores de nutrientes e metais pesado, sendo ignorado o seu efeito sobre o comportamento dos pesticidas, uma vez que a sua adição ao solo pode influenciar diretamente o potencial de sorção do pesticida e, consequentemente, sua eficácia agronômica, entre outros.

Segundo Wanner, Fuhr e Burauel (2005), a adição de resíduo orgânico ao solo pode reduzir a biodegradação dos pesticidas em decorrência do aumento da sorção dos mesmos ao solo, sendo que as substâncias húmicas são as principais responsáveis por esse processo. Worrall et al. (2001) ainda mencionam que as alterações estruturais na porosidade do solo também podem afetar o processo de sorção do pesticida ao solo. Cox et al. (2001) constataram redução na largura dos poros maiores do solo após adição de lodo de esgoto e sugerem que isso se deve à interação da matéria orgânica insolúvel (MOI, fase sólida) com as partículas do solo, bloqueando os poros maiores. Isto, por sua vez aumenta o contato do pesticida com a superfície do solo, favorecendo os processos de sorção e degradação.

Por outro lado, a adição de matéria orgânica dissolvida (MOD, fase líquida) beneficia o processo de lixiviação do pesticida no solo, reduzindo o seu potencial de sorção (LI; XING; TORELLO, 2005; BRICEÑO; PALMA; DURÁN, 2007). A MOD é muito semelhante estrutural e funcionalmente aos surfactantes e, por isso, pode aumentar a solubilidade de 
compostos de baixa solubilidade em água (KILE; CHIO, 1989). A fração predominante da MOD é de baixo peso molecular e, como tal, é altamente móvel em solos. Sendo assim, a MOD pode carrear os pesticidas na solução do solo ao longo do seu perfil, podendo aumentar o seu potencial de lixiviação no solo (GUO; CHOROVER, 2003; GRABER at al., 2001). Paralelamente, Fernandes et al. (2006) e Cox et al. (2001) observaram que a adição de MOD pode reduzir o potencial de sorção devido à competição entre as moléculas orgâncias dissolvidas e os pesticidas pelos sítios de sorção do solo, podendo assim levar ao aumento no potencial de lixiviação dos pesticidas. Por exemplo, Nelson et al. (1998) relataram que as taxas de lixiviação do napropamide em solos acrescidos de lodo de esgoto foram duas vezes maiores que nos solos originais.

Como a adição de lodo de esgoto ao solo implica na adição simultânea de MOD e MOI, fica difícil predizer as consequências da aplicação de lodo de esgoto sobre o comportamento de pesticidas em solo, uma vez que ambas as frações têm efeitos antagônicos no potencial de sorção dos pesticidas, o que demanda o desenvolvimento de mais estudos nesta área para entender a dinâmica destas interações.

Dentro deste contexto, a ametrina, um herbicida do grupo das triazinas, amplamente utilizada para a cultura da cana-de-açúcar no Brasil foi selecionada, pois pouco se sabe sobre seu comportamento ambiental em condições tropicais. Trata-se de um herbicida seletivo aplicado em pré e pós-emergência, controlando plantas daninhas em várias culturas. Devido a seu uso intensivo, alta persistência e alta solubilidade em água, a ametrina apresenta potencial de contaminar ambientes aquáticos, tanto por processos de escoamento superficial como de lixiviação (FERNANDES et al., 2006). Assim, o presente trabalho teve como objetivo avaliar o potencial de lixiviação da ametrina em solos tipicamente brasileiros, tratados com diferentes fontes de lodo de esgoto. Acredita-se que isto irá contribuir com informações que levem à otimização da aplicação de lodo de esgoto em áreas agrícolas. 


\subsection{MATERIAIS E MÉTODO}

\section{Ametrina}

Pertencente ao grupo das triazinas, a ametrina (2-etilamino-4-isopropilamino-6-metiltios-triazina) é um inibidor da fotossíntese utilizado como herbicida seletivo sistêmico, podendo ser aplicada em pré e pós emergência para controlar plantas daninhas anuais (folhas estreitas e largas) associadas a várias culturas.

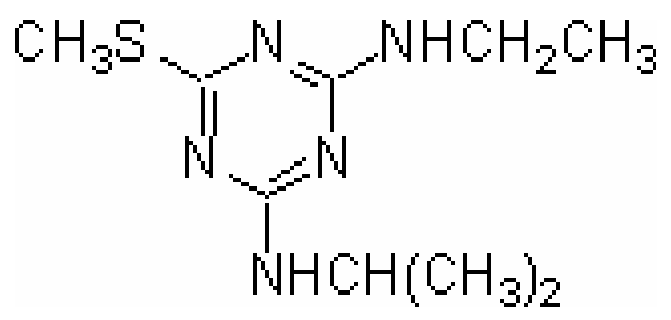

Figura 1. Fórmula estrutural da ametrina.

Como principais características da ametrina, destacam-se: solubilidade em água $=200$ $m g L^{-1}$ a $25^{\circ} \mathrm{C}$; pressão de vapor $=3,7 \times 10^{-4} \mathrm{~Pa}$; $\log \mathrm{K}_{\mathrm{ow}}=2,63$ e $\mathrm{K}_{\mathrm{oc}}=100$ a $930 \mathrm{~L} \mathrm{~kg}^{-1}$, herbicida ionizável, com caráter básico $\left(\mathrm{pK}_{\mathrm{a}}=4,1\right)$. Apresenta alta estabilidade em meios neutros, levemente ácidos ou levemente alcalinos. No solo, é um herbicida relativamente persistente $\left(\mathrm{DT}_{50}=70\right.$ a 129 dias), estando sujeito primariamente à degradação microbiana (ROBERTS et al., 1998). A dose de aplicação normalmente recomendada varia de 2,25 a 3,0 kg i.a. ha ${ }^{-1}$, dependendo da textura do solo. 
Para este estudo, foi utilizada uma molécula radiomarcada $\left({ }^{14} \mathrm{C}\right.$-ametrina $)$, com atividade específica $=1,05 \mu \mathrm{Ci} \mathrm{mg}{ }^{-1}$ e pureza $=95 \%$, tendo sido utilizada a maior dose de campo recomendada ( $3 \mathrm{~kg}$ i.a. ha $\left.{ }^{-1}\right)$, de modo a simular o pior cenário possível.

\section{Solo}

Dois tipos de solos com diferentes propriedades físico-químicas e com representação dentro da região canavieira do estado de São Paulo foram selecionados: Neossolo Quartzarênico Órtico Típico (RQ) e Latossolo Vermelho Distroférrico (LVdf). As amostras de solo foram coletadas na camada de 0,0 - 0,2 $\mathrm{m}$ de profundidade, secas ao ar e passadas em peneira com $2 \mathrm{~mm}$ de diâmetro. Posteriormente, sub-amostras foram encaminhadas ao Departamento de Ciência do Solo / ESALQ / USP para realização das análises físico-químicas (Tabela 1).

Para a análise granulométrica, foi utilizado o método do densímetro, enquanto que o alumínio trocável e os cátions trocáveis foram extraídos com $\mathrm{KCl} 1 \mathrm{~mol} \mathrm{~L}^{-1}$ e resina trocadora de íons, respectivamente. $\mathrm{O} \mathrm{pH}$ foi determinado em $\mathrm{CaCl}_{2} 0,01 \mathrm{~mol} \mathrm{~L}^{-1}$ e a acidez potencial $(\mathrm{H}+\mathrm{Al})$ foram estimadas com o uso do tampão SMP. O teor de matéria orgânica foi estimado com o uso do método colorimétrico (CAMARGO et al., 1986; MALAVOLTA; VITTI; DE OLIVEIRA, 1989; RAIJ; QUAGGIO, 1983). Além disso, foi feita uma prévia análise dos minerais de argila através de difratogramas de raio-x.

\section{Lodo de esgoto}

Dois tipos de lodos de esgoto foram selecionados com base na sua representatividade de uso agrícola e nos resultados de um estudo preliminar realizado com três tipos de lodo de 
esgoto. Os lodos selecionados, oriundos das estações de tratamento de esgoto das cidades de Jundiaí e Ribeirão Preto, pertencentes ao Estado de São Paulo, apresentaram comportamento contrastante, ora aumentando e ora reduzindo o potencial de sorção da ametrina nos solos estudados. As amostras foram coletadas e armazenadas em sacos plásticos e acondicionadas a $\pm 5{ }^{\circ} \mathrm{C}$, em câmara fria. Para a caracterização química deste material, sub-amostras foram enviadas ao Departamento de Ciências Exatas/ Laboratório de Química / ESALQ / USP (Tabela 2).

A determinação do nitrogênio foi feita de acordo com o método oficial empregado para fertilizantes orgânicos (BRASIL, 1988). O carbono orgânico foi determinado com base na oxidação do mesmo por dicromato de potássio por via úmida, na presença de ácido sulfúrico e com aquecimento externo (RODELLA, 1996). Os teores totais de fósforo, potássio, sódio, cálcio, magnésio, cobre e zinco foram determinados em extratos nítrico-perclórico de amostras secas e moídas. O teor de carbono orgânico dissolvido (COD) foi determinado com base na conversão do carbono orgânico total em $\mathrm{CO}_{2}$ e detecção por célula de infravermelho não dispersivo (Equipamento TOC $5000 \mathrm{~A}$ - Shimadzu). As amostras foram previamente purgadas com ar sintético 5.0 e $\mathrm{HCl} 2 \mathrm{~N}$ para retirada do carbono inorgânico.

A ETE de Jundiaí é concebida por lagoas aeradas de mistura completa seguidas de lagoas de sedimentação. O lodo biológico é dragado continuamente das lagoas de sedimentação, porém, particularidade operacional implementada após o início das atividades da ETE e o início da retirada e desaguamento de lodo, fez com que o lodo tenha uma permanência média de 12 meses no fundo destas lagoas, visando aumentar o seu grau de digestão através de processos anaeróbios. Na seqüência, o mesmo é destinado para tanques de equalização e injetado simultaneamente com suspensão de polímeros em centrífugas para seu desaguamento. O lodo desaguado é encaminhado para um pátio de secagem ao ar com 
revolvimento mecânico diário, onde permanece por período médio de 60 dias atingindo teores de sólidos próximos a $40 \%$ (informação pessoal) ${ }^{6}$.

Na ETE de Ribeirão Preto, de concepção de lodos ativados convencional, o esgoto passa por gradeamento grosso, intermediário e fino, seguindo para um desarenador e desengordurador. Em seguida, o lodo de esgoto segue para o decantador primário, onde ocorre a separação de sólidos sedimentáveis e dissolvidos, e vai para o reator biológico para sofrer o tratamento biológico. Após este tratamento, o lodo passa por decantadores e segue para os biodigestores, onde ocorre a estabilização através de processo biológico anaeróbico. Por fim, o lodo é desaguado (informação pessoal) ${ }^{7}$.

De forma geral, o lodo de Jundiaí apresenta-se mais digerido ou estabilizado que os outros, pois o seu tratamento é mais lento e, portanto, tende a apresentar parcela maior de substâncias orgânicas recalcitrantes como óleos, graxas e resinas. Já o lodo de Ribeirão Preto, apresenta processamento mais rápido e isto faz com apresente maior biomassa e matéria orgânica facilmente decomponível quando comparado ao lodo de Jundiaí. Além disso, o lodo de Jundiaí quando desaguado mostra-se neutro $(\mathrm{pH} 7,0)$, sendo que os processos de nitrificação que ocorrem durante sua secagem por revolvimento mecânico o torna levemente ácido. Isto certamente acabaria ocorrendo com o lodo de Ribeirão Preto, caso fosse depositado e submetido à aeração (informação pessoal) ${ }^{3}$.

\footnotetext{
${ }^{6}$ OLIVEIRA, F.C. ETE - Jundiaí. Mensagem eletrônica recebida por marchese@cena.usp.br em 26 fev. 2007.

${ }^{7}$ FERREIRA, C.R. ETE - Ribeirão Preto. Mensagem eletrônica recebida por marchese@ cena.usp.br em 15 mar. 2007.
} 
Tabela 1 - Propriedades físico-químicas dos solos estudados.

\begin{tabular}{|c|c|c|c|c|c|c|c|}
\hline Solo & pH & CTC $^{(1)}$ & M.O. ${ }^{(2)}$ & Areia & Silte & Argila & Classe textural \\
\hline & $\mathrm{CaCl}_{2}$ & mmolc $\mathrm{dm}^{-3}$ & $\mathrm{mg} \mathrm{dm}^{-3}$ & ............ & $\ldots \% \ldots$ & $\ldots \ldots \ldots \ldots$ & \\
\hline RQ & 4,1 & 39,6 & 20 & 90 & 2 & 8 & Areia \\
\hline LVdf & 4,9 & 102,6 & 45 & 43 & 9 & 48 & Argila \\
\hline
\end{tabular}

Tabela 2 - Caracterização química das amostras de lodos de esgoto.

\begin{tabular}{|c|c|c|c|c|c|c|c|c|c|c|c|c|}
\hline & $\mathrm{C}_{\text {total }}$ & & $\mathbf{D}^{(1)}$ & pH & $\mathbf{P}$ & $\mathbf{K}$ & $\mathrm{Na}$ & $\mathrm{Ca}$ & Mg & $\mathbf{N}$ & $\mathrm{Cu}$ & Zn \\
\hline \multirow{3}{*}{ eto } & $\mathrm{g} \mathrm{kg}^{-1}$ & $\mathrm{mg} \mathrm{L}^{-1}$ & $\mathrm{~g} \mathrm{~kg}^{-1}$ lodo & $\left(\mathrm{CaCl}_{2}\right)$ & \multicolumn{6}{|c|}{..................... $\mathrm{g} \mathrm{kg}^{-1}$} & \multicolumn{2}{|c|}{$\ldots \mathrm{mg} \mathrm{kg}^{-1}$.. } \\
\hline & 404,7 & 289,2 & 17,3 & 8,1 & 19,4 & 1,1 & 0,9 & 23,8 & 4,9 & 22,2 & 685 & 1415 \\
\hline & 364,9 & 25,7 & 1,5 & 5,1 & 7,7 & 1,5 & 2,1 & 20,6 & 5,6 & 15,7 & 669 & 1161 \\
\hline
\end{tabular}

${ }^{(1)} \mathrm{COD}=$ carbono orgânico dissolvido 


\section{Experimento de lixiviação}

O lodo de esgoto foi aplicado ao solo na dose correspondente a $20 \mathrm{t} \mathrm{ha}^{-1}$ (peso seco), no mesmo dia em que as colunas de solo foram empacotadas. Delineamento experimental totalmente casualizado foi adotado, com fatorial 2 (solos) x 3 (sem lodo +2 fontes de lodo) e com três repetições (colunas de solo) para cada tratamento.

Para o estudo, foram utilizadas colunas de vidro $(30 \mathrm{~cm}$ de comprimento e $5 \mathrm{~cm}$ de diâmetro interno) com formato cônico na extremidade inferior. Lã de vidro e areia esterilizada (com $\mathrm{HCl}$ ) foram adicionados à parte cônica da coluna como materiais de suporte e para evitar a contaminação do lixiviado com as partículas de solo. As amostras de solo (testemunha) mais aquelas devidamente tratadas com as fontes de lodo (tratamentos) foram empacotadas manualmente nas colunas até a profundidade de $30 \mathrm{~cm}$ (Figura 2). Lã de vidro também foi acondicionada na parte superior da coluna para promover dispersão homogênea da chuva simulada. As colunas de solo foram saturadas, por capilaridade, sendo que a solução em excesso foi percolada pelo período aproximado de 4 horas (Figura 3). Depois disso, solução de ${ }^{14} \mathrm{C}$-ametrina foi aplicada às colunas em concentração correspondente à dose máxima de 3,0 kg i.a. ha ${ }^{-1}$ (ou 21,5 kBq/coluna).

As colunas foram colocadas numa sala semi-escura, com controle de temperatura $(25 \pm$ $2{ }^{\circ} \mathrm{C}$ ). Posteriormente, com o auxílio de bomba peristáltica, as mesmas passaram a ser lixiviadas com solução aquosa de $\mathrm{CaCl}_{2}$ 0,01 mol L $\mathrm{L}^{-1}$, num fluxo de cerca de $200 \mathrm{~mm}$ uniformemente distribuído durante 48 horas (Figura 4). A solução lixiviada foi coletada em intervalos de 12 horas e alíquotas de $5 \mathrm{~mL}$ foram analisadas por espectrometria de cintilação líquida (ECL). 
Após as 48 horas, ar pressurizado foi aplicado na extremidade inferior para remover os solos das colunas, sendo estes seccionados em camadas de $5 \mathrm{~cm}$, acondicionados em bandejas de alumínio e secos ao ar (Figura 5). Para determinação (por ECL) dos resíduos ligados ao solo, sub-amostras de $0,4 \mathrm{~g}$ do solo seco ao ar passaram pelo processo de combustão, através de um oxidador biológico com subseqüente aprisionamento do ${ }^{14} \mathrm{CO}_{2}$ liberado pela solução captadora (monoetanolamina).

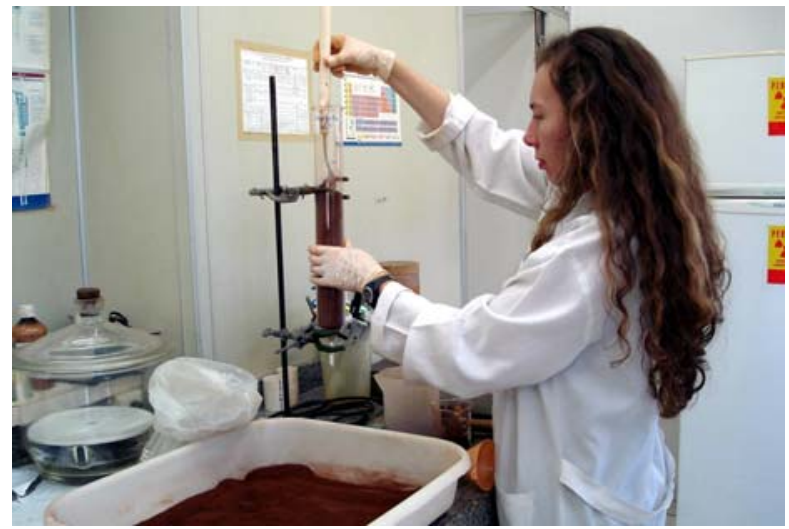

Figura 2. Empacotamento das colunas de solo.

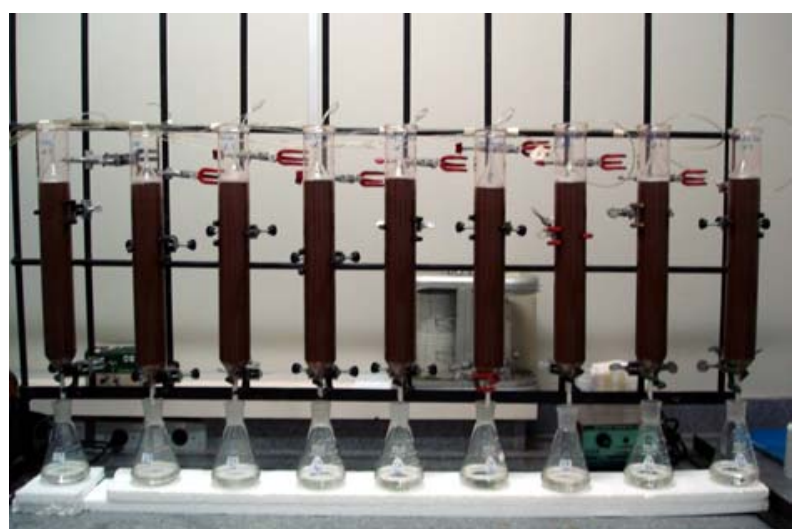

Figura 4. Experimento de lixiviação: gotejamento, colunas e material percolado.

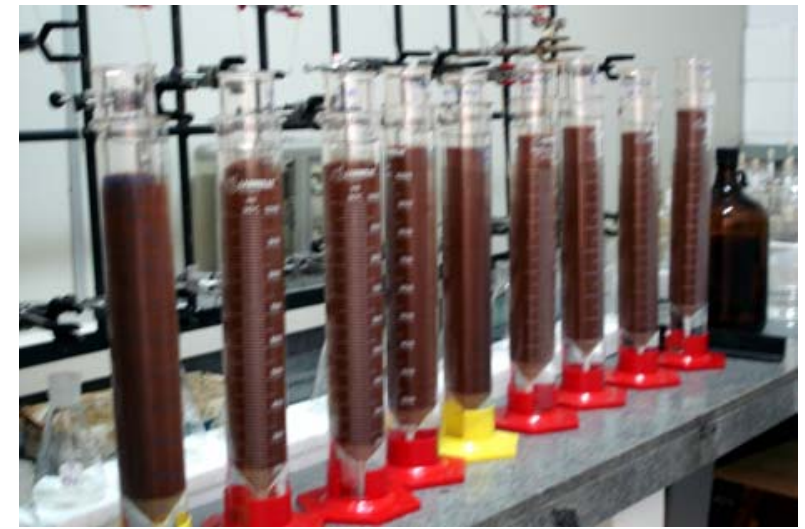

Figura 3. Saturação das colunas $\operatorname{com} \mathrm{CaCl}_{2}$ $0,01 \mathrm{~mol} \mathrm{~L}^{-1}$, por capilaridade.

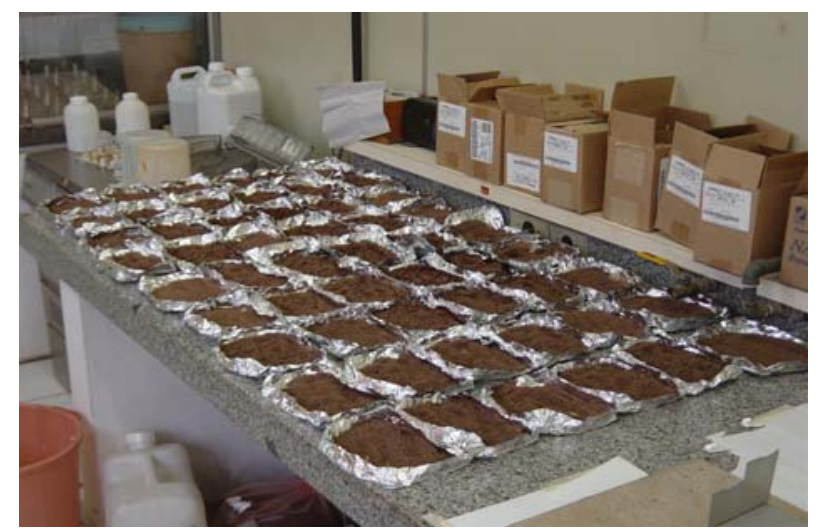

Figura 5. Fracionamento das colunas, em camadas de $5 \mathrm{~cm}$. 


\subsection{RESULTADOS E DISCUSSÃO}

Vários critérios podem ser utilizados para avaliar o potencial de lixiviação de pesticidas no solo. De acordo com Cohen et al. (1984 apud WELLS; WALDMAN; BEHL, 1995, p.265) $)^{4}$ pesticidas com valor de $\mathrm{K}_{\mathrm{d}}$ inferior a $5 \mathrm{~mL} \mathrm{~g}^{-1}, \mathrm{~K}_{\mathrm{oc}}$ inferior a $300-500 \mathrm{~g} / \mathrm{g}$ carbono e solubilidade em água superior a $30 \mathrm{mg} \mathrm{L}^{-1}$ apresentam potencial de lixiviação. Segundo o critério adotado pelo California Departament of Food and Agriculture (CDFA), proposto por Widerson e Kim (1986 apud INOUE, 2002, p.74) ${ }^{5}$, os pesticidas com $\mathrm{K}_{\mathrm{oc}}$ menor que $512 \mathrm{~L}$ $\mathrm{kg}^{-1}$ e meia-vida superior a 11 dias são classificados como lixiviáveis. Outra forma de se avaliar o potencial de lixiviação de pesticidas é através do índice GUS, índice de vulnerabilidade de águas subterrâneas, proposto por Gustafson (1989 apud INOUE, 2002, p.74) ${ }^{6}$ e calculado a partir dos valores de meia-vida e $\mathrm{K}_{\mathrm{oc}}$ do pesticida. Neste caso, pesticidas com GUS $<1,8$ não possuem potencial de lixiviação, 1,8 $<$ GUS $<2,8$ possuem potencial de lixiviação intermediário e GUS > 2,8 são considerados lixiviáveis.

INOUE (2002) classificou a ametrina como lixiviável segundo os critérios do CDFA e Cohen e com potencial de lixiviação intermediário segundo o GUS. Paralelamente, resultados preliminares relativos aos estudos de sorção e dessorção realizados nos mesmos solos e fontes de lodo, mostraram que ametrina apresentou potencial de lixiviação no solo $R Q\left(K_{d}\right.$ variou de 2,68 a 4,43 $\mathrm{L} \mathrm{kg}^{-1}$ ), principalmente quando o solo foi tratado com o lodo de Ribeirão Preto. Já no solo LVdf, o valor de $\mathrm{K}_{\mathrm{d}}$ variou de 4,30 a 6,48 $\mathrm{L} \mathrm{kg}^{-1}$, com o menor valor também obtido

\footnotetext{
${ }^{3}$ OLIVEIRA, F.C. ETE - Jundiaí. Mensagem eletrônica recebida por marchese@cena.usp.br em 26 fev. 2007.

${ }^{4}$ COHEN, S.Z.; CREEGER, S.M.; CARSEL, R.F.; ENFIELD, C.G. Potencial pesticide contamination of groundwater from agricultural uses. In: Treatment and disposal of pesticide wastes, KRUEGAR, R.F.; SEIBER, J.N. Washington: American Chemical Society, 1984.

${ }^{5}$ WIDERSON, M.R.; KIM, K.D. The pesticide contamination prevention act: setting specific numerical values. Sacramento: California Departament Food and Agriculture, Environmental Monitoring and Pesticide Management, 287p.,1986.

${ }^{6}$ GUSTAFSON, D.I. Groundwater ubiquity score: a simple method for assessing pesticide leachibility.

Environmental Toxicology Chemistry, v.8, n.4, p.339-357, 1989.
} 
para o tratamento com o lodo de Ribeirão Preto, portanto, sendo maior o seu potencial de lixiviação neste cenário.

No entanto, os resultados deste estudo mostram que as quantidades de ametrina lixiviadas através das colunas de solo foram insignificantes em todos os tratamentos $(<1,0 \%$ da quantidade de ametrina inicialmente aplicada em todos os tratamentos, Tabela 3). Em contrapartida, as quantidades de resíduos de ${ }^{14} \mathrm{C}$-ametrina retidas no solo corresponderam a praticamente o total de sua quantidade aplicada. Além disso, a radioatividade recuperada variou de 100 a $110 \%$ (Tabela 3), o que está dentro dos limites aceitáveis (90 a 110\%) segundo a norma da Organisation for Economic Co-Operation and Development (2004).

Tabela 3 - Parâmetros resultantes do estudo de lixiviação nos diferentes tratamentos.

\begin{tabular}{|c|c|c|c|}
\hline Tratamento & Total lixiviado & Total oxidado ${ }^{(1)}$ & Total recuperado ${ }^{(2)}$ \\
\hline & \multicolumn{3}{|c|}{$\%$ do aplicado ${ }^{(3)}}$. \\
\hline LVdf & $0,08 \pm 0,02^{(4)}$ & $101 \pm 6$ & $101 \pm 6$ \\
\hline LVdf + Jundiaí & $0,05 \pm 0,04$ & $100 \pm 6$ & $100 \pm 6$ \\
\hline LVdf + Ribeirão Preto & $0,13 \pm 0,02$ & $110 \pm 2$ & $110 \pm 2$ \\
\hline RQ & $0,96 \pm 0,37$ & $106 \pm 8$ & $107 \pm 7$ \\
\hline RQ + Jundiaí & $0,14 \pm 0,07$ & $103 \pm 10$ & $103 \pm 10$ \\
\hline RQ + Ribeirão Preto & $0,01 \pm 0,01$ & $109 \pm 3$ & $109 \pm 0$ \\
\hline $\begin{array}{l}\text { (1) Total oxidado }=\text { qu } \\
\text { (2) Total recuperado = } \\
\text { (3) } \% \text { média em relaçã } \\
\text { (4) Média } \pm \text { desvio pad }\end{array}$ & $\begin{array}{l}\text { dade de }{ }^{14} \mathrm{C} \text {-ametr } \\
\text { l lixiviado }+ \text { total } \\
\text { quantidade de }{ }^{14} \mathrm{C}\end{array}$ & $\begin{array}{l}\text { Total recuperado }=\text { total lixiviado }+ \text { total oxidado } \\
\% \text { média em relação à quantidade de }{ }^{14} \mathrm{C} \text {-ametrina aplicada inicialmente }\end{array}$ & mente \\
\hline
\end{tabular}

Estes resultados revelam que apesar da ametrina apresentar, pelo menos teoricamente, potencial de lixiviação quando apenas seu potencial de sorção é analisado, isto não necessariamente corresponde à realidade dos fatos, uma vez que testes mais apropriados em colunas, que consideram a estrutura tridimensional do solo e o fluxo de água em condições mais realísticas, entre outros, mostraram baixo potencial de lixiviação para esta molécula, 
inclusive nas colunas de solo que não receberam lodo de esgoto. De forma geral, do ponto de vista ambiental, não se pode observar diferenças nos tratamentos (tipos de solo x fontes de lodo) quanto à quantidade lixiviada de ametrina, embora alguns trabalhos sugiram que a retenção de pesticidas em colunas de solo seja maior nas colunas que receberam solos acrescidos de matéria orgânica (GUO et al., 1993; ALBARRÁN et al.,2004).

Na literatura são praticamente inexistentes os relatos sobre problemas de lixiviação com a ametrina, principalmente em condições tropicais. O único trabalho encontrado relata que a ametrina foi detectada em água subterrânea de um aqüífero não confinado na bacia de Mélarchez (França), nas concentrações de 50 a $350 \eta \mathrm{g} \mathrm{L}^{-1}$, durante os períodos de abril a outubro de 1991 a 1993, sendo que estes picos de concentrações estariam relacionados aos fenômenos de precipitação e escoamento superficial ocorridos após os períodos de aplicação (GARMOUMA et al., 1997).

Em adição ao baixo potencial de lixiviação da ametrina, também se pode observar que a grande parte da ametrina ( $>95 \%$ do aplicado) ficou retida na camada de 0 a $10 \mathrm{~cm}$ de profundidade em todos os tratamentos (Figura 2). Tal fato ratifica o baixo potencial de lixiviação da ametrina, demonstrando o seu baixo risco de contaminar águas subterrâneas. 


\subsection{CONCLUSÕES}

Os resultados obtidos permitem concluir que a ametrina apresentou baixo potencial de lixiviação tanto nos solos originais como nos solos acrescidos de lodo de esgoto, não evidenciando dessa forma, a influência da adição de lodo de esgoto sobre o potencial de lixiviação do pesticida em questão. Além disso, a ametrina ficou retida nas camadas mais superficiais do solo, o que reduz o risco de contaminação de águas subterrâneas. Dessa forma, a ametrina não parece ser um pesticida que apresenta um risco sério de contaminação de águas subterrâneas nos solos estudados, porém, por ficar retida mais nas camadas superiores, pode ser carreada com partículas de solo, podendo contaminar águas superficiais. 


\section{CONCLUSÕES GERAIS}

O potencial de sorção da ametrina ao solo é função das diferentes propriedades do solo e do lodo. De forma geral, pode-se explicar o seu potencial de sorção ao solo em função do teor de matéria orgânica, do pH e da fração de argilas do tipo 2:1.

Solos argilosos com maiores teores de matéria orgânica e argilas do tipo 2:1, como é o caso do PV, apresentaram alto potencial de sorção da ametrina, enquanto que solos arenosos com baixos teores de matéria orgânica, como são os casos do LVd e RQ, apresentaram moderado potencial de sorção. Paralelamente, a dessorção da ametrina foi maior nos solos RQ e LVd, nos quais a sorção foi menor, sendo a histerese da reação maior no solo PV.

Além do valor de $\mathrm{pH}$, os teores de carbono orgânico total e dissolvido do lodo também influenciam diretamente o potencial de sorção da ametrina. A aplicação de lodos menos estabilizados, com biomassa e material orgânico menos recalcitrante e, consequentemente, com maiores valores de carbono orgânico dissolvido e pH, como é o caso do lodo de Ribeirão Preto, tende a diminuir o potencial de sorção da ametrina. Por outro lado, a adição de lodos mais recalcitrantes, como o de Jundiaí, em solos arenosos com menores teores de matéria orgânica tende a aumentar o potencial de sorção da ametrina, uma vez que estes solos apresentam menor capacidade tampão. Solos argilosos, com maior capacidade tampão, são mais resistentes às mudanças no potencial de sorção.

Teoricamente, a aplicação do lodo de Jundiaí em solos como o RQ e o LVd representariam as situações em que poderia ocorrer diminuição da eficácia agronômica da ametrina, pois ocorreu aumento do seu potencial de sorção.

A ametrina apresentou baixo potencial de lixiviação nos solos estudados (RQ e LVdf), sendo que a adição das diferentes fontes de lodo nada influenciou neste comportamento. Além disso, a grande maioria das moléculas de ametrina ficou retida nas camadas superficiais do 
solo (0 a $10 \mathrm{~cm})$, o que mostra o seu baixo potencial de contaminação de águas subterrâneas.

Para minimizar os impactos e riscos de contaminação ambiental, bem como evitar problemas de redução na eficácia agronômica, é preciso avaliar todas as variáveis envolvidas no comportamento de pesticidas no solo.

É necessário que mais estudos sobre o comportamento de pesticidas em solos tratados com lodo de esgoto sejam conduzidos em regiões tropicais, especialmente em situações em que haja aplicações seqüenciais do resíduo como fertilizante orgânico, principalmente em condições mais realistas de campo. 


\section{REFERÊNCIAS}

ABREU JUNIOR, C. H.; MURAOKA, T.; OLIVEIRA, F. C. Cátions trocáveis, capacidade de troca de cátions e saturação por bases em solos brasileiros adubados com composto de lixo urbano. Scientia Agricola, Piracicaba, v. 58, n. 4, p. 813-824, 2001.

AHMAD, R..; KOOKANA, R. S.; ALSTON, A. M. Sorption of ametryn and imazethapyr in twenty-five soils from Pakistan and Australia. Journal of Environmental Science and Health (B), New York, v. 36, n. 2, p. 143-160, 2001.

ALBARRÁN, A. et al. Behavior of simazine in soil amended with the final residue of the olive-oil extraction process. Chemosphere, Oxford, v. 54, p. 717-724, 2004.

ALVES FILHO, J. P. Agrotóxicos e Agenda 21: sinais e desafios da transição para uma agricultura sustentável. Disponível em:

$<$ http://www.iac.sp.gov.br/Centros/centro\%20de $\% 20$ engenharia $\% 20 \mathrm{e} 20 \% 20$ automa $\% \mathrm{C} 3 \% \mathrm{~A} 3$ \%sintag/AjoséPrado.PDF>. Acesso em: 14 fev. 2007.

ANDREOLI, C. V.; PEGORINI, E. S. Gestão de biossólidos: Situação e perspectivas. In: SEMINÁRIO SOBRE GERENCIAMENTO DE BIOSSÓLIDOS DO MERCOSUL, 1., 1998, Curitiba. Anais... Curitiba: Companhia de Saneamento do Paraná; Associação Brasileira de Engenharia Sanitária e Ambiental, 1998.

ANTONIOUS, G. F.; PATTERSON, M. A.; SYNDER, J. C. Pesticide residues in soil and quality of potato grown with sewage sludge. Bulletin of Environmental Contamination and Toxicology, New York, v. 71, p. 315-322, 2003.

ARMAS, E. D. et al. Uso de agrotóxicos em cana-de-açúcar na Bacia do Rio Corumbataí: o risco de poluição hídrica. Química Nova, São Paulo, v. 28, n. 6, p. 975-982, 2005.

BARRIUSO, E.; HOUOT, S.; SERRA-WITTLING, C. Influence of compost addition to soil on the behaviour of herbicides. Pesticide Science, London, v. 49, p. 65-75, 1997.

BECKMANN, M. Aspectos ecotoxicológicos de químicos agrícolas. Jaboticabal: FCAV/UNESP. Disponível em: $<$ http://br.monografias.com/trabalhos/aspectosecotoxicologicos/aspectos-ecotoxicologicos2.shtml>. Acesso em: 14 fev. 2007.

BELLUCK, D. A.; BENJAMIN, S. L.; DAWSON, T. Groundwater contamination by atrazine and its metabolites: Risk assessment, policy, and legal implications. In: L. SOMASUNDARAM, L.; COATS, J. R. (Ed.). Pesticide transformation products: fate and significance in the environment. Washington: American Chemical Society Press, 1991. p. 254-273. (Symposium Series, 459).

BETTIOL, W.; CAMARGO, O. A. A disposição de lodo de esgoto em solo agrícola. In: Lodo de esgoto: impactos ambientais na agricultura. Jaguariúna: Embrapa Meio Ambiente, 2006. p. 25-36. 
BETTIOL, W.; CAMARGO, O. A. Impacto ambiental do uso agrícola do lodo de esgoto. Jaguariúna: Embrapa Meio Ambiente, 2000. 312p.

BITTENCOURT, E. Embrapa comprova prejuízos aos recursos hídricos por defensivos e pesquisa opções de menor impacto no meio ambiente. Disponível em: < http://www.agrisustentavel.com/toxicos/residuorh.htm. Acesso em: 15 mar. 2007.

BLANCHOUD, H.; FARRUGIA, F.; MOUCHEL, J. M. Pesticide uses and transfers in urbanised catchments. Chemosphere, Oxford, v. 55, p. 905-913, 2004.

BOCQUENÉ, G.; FRANCO, A. Pesticide contamination of the coastline of Martinique. Marine Pollution Bulletin, London, v. 51, p. 612-619, 2005.

BOESTEN, J. J. T. I. Sensitivity analysis of a mathematical model for pesticide leaching to groundwater. Pesticide Science, London, v. 31, p. 375-388, 1991.

BOUWER, H. Agricultural chemicals and groundwater quality. Journal of Soil and Water Conservation, Ankeny, v. 42, p. 184-189, 1990.

BRADY, N. C. Soil organic matter and organic soils. In: The nature and properties of soils. 10. ed. New York: Macmillan Publishing Company, 1990. p. 279-313.

BRASIL. Ministério da Agricultura. Secretaria Nacional de Defesa Agropecuária. Análise de corretivos, fertilizantes e inoculantes: métodos oficiais. Brasília, 1988. 104 p.

BRICEÑO, G.; PALMA, G.; DURÁN, N. Influence of Organic Amendment on the Biodegradation and Movement of Pesticides. Critical Reviews in Environmental Science and Technology, Boca Raton, v. 37, p. 233-271, 2007.

BRONDI, S. H. G.; LANÇAS, F. M. HPLC determination of pesticide residues widely employed in sugar-cane cultures in river water samples. Journal of Liquid Chromatography \& Related Technologies, New York, v. 27, n. 1, p. 171-179, 2004.

BUSINELLI, D. Pig slurry amendment and herbicide coapplication effects on s-triazine mobility in soil: an adsorption-desorption study. Journal of Environmental Quality, Madison, v. 26, p. 102-108, 1997.

CAMARGO, O. A.; BETTIOL, W. Agricultura: opção animadora para a utilização de lodo de esgoto. O Agronômico, Campinas, v. 55, n. 2/3, p. 13-16, 2000.

CAMARGO, O. A. et al. Métodos de análise química, mineralógica e física de solos do Instituto Agronômico de Campinas. Campinas: IAC, 1986. 94 p. (Boletim Técnico, 106).

CELIS, R.; BARRIUSO, E.; HOUOT, S. J. Sorption and desorption of atrazine by sludgeamended soil: dissolved organic matter effects. Journal of Environmental Quality, Madison, v. 27, n. 6, p. 1348-1356, 1998.

CERDEIRA, A. L. et al. Herbicide residue in soil and water from sugarcane area in Brazil. In: CONGRES MUNDIAL DE SCIENCE DU SOL, 16., 1998, Montpellier. Anais... Montpellier, 1998. 
CERDEIRA, A. L. et al. Efeito de sistemas de cultivo com cana-de-açúcar sobre a lixiviação dos herbicidas do grupo das triazinas em região de recarga do Aquífero Guarani. Jaguariúna: Embrapa Meio Ambiente, 2005. (Boletim de Pesquisa e Desenvolvimento, 32).

CHAIM, A. et al. Manejo de agrotóxico e qualidade ambiental: manual técnico. Jaguariúna: Embrapa Meio Ambiente, 1999. 34 p. (Documentos, 5).

CHAPLAIN, V. et al. Influence of the formulation on the sorption and the mobility of diuron in soil. Bulletin of Environmental Contamination and Toxicology, New York, v. 66, n. 5, p. 664-670, 2001.

CHEAH, U. B; KIRKWOOD, R. C.; LUM, K. Y. Adsorption, desorption and mobility of four commoly used pesticides in Malaysian agricultural soils. Pesticide Science, London, v. 50, p. 53-63, 1997.

CHIOU, C.T. Theoretical considerations of the partition uptake of nonionic organic compounds by soil organic matter. In: SAWHNEY, B.L.; BROWN, K. Reactions and movement of organic chemicals in soils. Madison: Soil Science Society of America, Inc., 1989. p. 1-31.

COX, L. et al. Effect of exogenous carbon on movement of simazine and 2,4-D in soils. Soil Science Society American Journal, Madison, v. 65, p. 1688-1695, 2001.

DE JONGE, H. et al. Transport of di(2-ethylhexyl)phthalate (DEHP) applied with sewage sludge to undisturbed and repacked soil columns. Journal of Environmental Quality, Madison, v. 31, p. 1963-1971, 2002.

DE LUNA, A. J.; DE SALES, L. T.; DA SILVA, R. F. Agrotóxicos: responsabilidade de todos (uma abordagem da questão dentro do paradigma do desenvolvimento sustentável). Jaboticabal: UNESP, 2004. Disponível em: http://www.prt6.gov.br/forum/downloads/Artigo1 Adeilson.doc. Acesso em 25 fev. 2007.

DE MELO, V. P. et al. Atributos físicos de latossolos adubados durante cinco anos com biossólido. Pesquisa Agropecuária Brasileira, Brasília, v. 39, n. 1, p. 67-72, 2004.

DOS SANTOS, A. D. Estudo das possibilidades de reciclagem dos resíduos de tratamento de esgoto da região metropolitana de São Paulo. 2003. 265 f. Dissertação (Mestrado) - Escola Politécnica, Universidade de São Paulo, São Paulo, 2003.

EGIARTE, G. et al. Study of the chemistry of an acid soil column and of the corresponding leachates after the addition of an anaerobic municipal sludge. Chemosphere, Oxford, v. 65, p. 2456-2467, 2006.

ENFIELD, C. G. Chemical transport facilitated by multiphase flow systems. Water Science and Technology, London, v. 17, p. 1-12, 1985.

FERNANDES, M. C. et al. Organic amendments affecting sorption, leaching and dissipation of fungicides in soils. Pesticide Management Science, London, v. 62, p.1207-1215, 2006. 
FERREIRA, C. R. Publicação eletrônica [mensagem pessoal]. Mensagem recebida por marchese@,cena.usp.br em 15 mar 2007.

FLURY, M. J. Experimental evidence of transport of pesticides through field soils-a review. Journal of Environmental Quality, Madison, v. 25, p. 25-45, 1996.

FUTCH, S. H.; SINGH, M. Herbicide mobility using soil leaching columns. Bulletin of Environmental Contamination and Toxicology, New York, v. 62, p. 520-529, 1999.

GARMOUMA, M. et al. Seasonal transport of herbicides (triazines and phenylureas) in a small stream draining an agricultural basin: Mélarchez (France). Water Research, New York, v. 31, n. 6, p. 1489-1503, 1997.

GASCÓ, G.; LOBO, M. C.; GUERRERO, F. Land application of sewage sludge: A soil columns study. Water SA, Pretoria, v. 31, n. 3, p. 309-318, 2005.

GILCHRIST, G. F. R. et al. Atrazine interactions with clay minerals: kinetics and equilibria of sorption. Journal of Agricultural and Food Chemistry, Washington, v. 41, p. 1748$1755,1993$.

GONÇALVES, J. L. M. et al. Aplicabilidade de biossólido em plantações florestais: II. Efeito na fertilidade do solo, nutrição e crescimento das árvores. In: BETTIOL, W.; CAMARGO, O.A. Impacto ambiental do uso agrícola do lodo de esgoto. Jaguariúna: Embrapa Meio Ambiente, 2000. p. 179-196.

GRABER, E. R.; DROR, I.; BERCOVICH, F. C.; ROSNER, M. Enhanced transport of pesticides in a field trial with treated sewage sludge. Chemosphere, Oxford, v. 44, p. 805$811,2001$.

GREEN, R. E. et al. Herbicide from cropped watersheds in streams and estuaries sediments in Hawaii. Journal of Environmental Quality, Madison, v. 6, p. 145-154, 1977.

GREEN, R. E.; KARICKHOFF, S. W. Sorption estimates for modeling. In: CHENG, H. H. Pesticide in the soil environment: processes, impacts, and modeling. Madison: SSSA, 1990. p. 79-102.

GROVER, R. Adsorption and desorption of urea herbicides in soils. Canadian Journal of Soil Science, Ottawa, v. 35, n. 2, p. 127-135, 1975.

GUO, L. et al. Sorption and movement of alachlor in soil modified by carbon-rich wastes. Journal of Environmental Quality, Madison, v. 22, p. 186-194, 1993.

GUO, M.; CHOROVER, J. Transport and fractionation of dissolved organic matter in soil columns. Soil Science, New Brunswick, v. 168, p. 101-118, 2003.

HABERHAUER, G. et al. Response of sorption processes of MCPA to the amount and origin of organic matter in a long-term field experiment. European Journal of Soil Science, Oxford, v. 52, p. 279-286, 2001. 
HUANG, X. et al. Herbicide runoff along highways. 2. Sorption control. Environmental Science \& Technology, Easton, v. 8, n. 12, p. 3272-3278, 2004.

ILANI, T.; SCHULZ, E.; CHEFETZ, B. Interactions of Organic Compounds with Wastewater Dissolved Organic Matter: Role of Hydrophobic Fractions. Journal of Environmental Quality, Madison, v. 34, p. 552-562, 2005.

INOUE, M. H. Potencial de lixiviação de herbicidas e dinâmica de atrazina e diuron em uma litossequência do Estado do Paraná. 2002. 74 f. Dissertação (Mestrado) Universidade Estadual de Maringá, Maringá, 2002.

INOUE, M. H. et al. Critérios para avaliação do potencial de lixiviação dos herbicidas comercializados no estado do Paraná. Planta Daninha, Rio de Janeiro, v. 21, n. 2, p. 313 323, 2003.

INSTITUTO BRASILEIRO DE GEOGRAFIA E ESTATÍSTICA. IBGE. Levantamento sistemático da produção agrícola. Rio de Janeiro, 2006. Disponível em: http://www.ibge.gov.br/home/estatistica/indicadores/agropecuaria/lspa/lspa01200705.shtm.

Acesso em: 17 fev. 2007.

KILE, D. E.; CHIO, C. T. Water solubility enhancement of DDT and trichlorobenzene by some surfactants below and above the critical micelle concentration. Environmental Science \& Technology, Easton, v. 23, p. 832-838, 1989.

KOSKINEN, W. C.; HARPER, S. S. The retention process: mechanisms. In: CHENG, H. H. et al. (Ed.). Pesticides in the soil environment: Processes, impacts, and modeling. Madison: SSSA, 1990. p. 51-77.

LAABS, V. et al. Pesticides in surface water, sediment, and rainfall of the northeastern Pantanal basin, Brazil. Journal of Environmental Quality, Madison, v. 31, n. 5, p. 16361648, 2002.

LANGENBACH, T.; SCHROLL, R.; PAIM, S. Fate and distribution of ${ }^{14} \mathrm{C}$-atrazine in tropical soils. Chemosphere, Oxford, v. 40, p. 449-455, 2000.

LAVORENTI, A.; PRATA, F.; REGITANO, J.B. Comportamento de pesticidas em solos fundamentos. Tópicos em Ciência do Solo, Viçosa, v. 3, p. 335-400, 2003.

LEE, D. Y.; FARMER, W. J.; AOCHI, Y. Sorption of napropamide on clay and soil in the presence of dissolved organic matter. Journal of Environmental Quality, Madison, v. 19, p. 567-573, 1990.

LI, K.; XING, B.; TORELLO, W. Effects of organic fertilizer derived dissolved organic matter on pesticides sorption and leaching. Environmental Pollution, London, v. 134, p. 187-194, 2005.

MALAVOLTA, E.; VITTI, G. C.; DE OLIVEIRA, S. A. Avaliação do Estado nutricional das plantas: princípios e aplicações. Piracicaba: POTAFOS, 1989. 201 p. 
MARTIN-SANCHEZ, M. J. et al. Efficiency of different clay minerals modified with a cationic surfactant in the adsorption of pesticides: Influence of clay type and pesticide hydrophobicity. Applied Clay Science, Amsterdam, v. 31, p. 216-228, 2006.

MCDONALD, L. et al. Pesticide mobility on a hillside soil in St. Lucia. Agriculture, Ecosystems and Environment, Amsterdam, v. 72, p. 181-188, 1999.

MELO, W. J.; MARQUES, M. O. Potencial do lodo de esgoto como fontes de nutrientes para as plantas. In: BETTIL, W.; CAMARGO, O. A. Impacto ambiental do uso agrícola do lodo de esgoto. Jaguariúna: Embrapa Meio Ambiente, 2000. p. 109-141.

MELO, W. J.; MARQUES, M. O.; MELO, V. P. O uso do biossólido e as propriedades do solo. In: TSUTIYA, M. T. et al. Biossólidos na agricultura. São Paulo: ABES/SP, 2002. p. 289-364.

MILES, C. J.; PFEUFFER, R. J. Pesticides in canals of South Florida. Archives of Environmental Contamination and Toxicology, New York, v. 31, p. 337-345, 1997.

MORILLO, E. et al. Effect of two organic amendments on norflurazon retention and release by soils of different characteristics. Environmental Science \& Technology, Easton, v. 36, n. 20, p. 43194325, 2002.

MULLER, K. et al. Point-and nonpointsource pesticide contamination in the Zwester Ohm catchment, Germany, Journal of Environmental Quality, Madison, v. 31, p. 309-318, 2002.

NARAMABUYE, F. X.; HAYNES, R. J. Effect of organic amendments on soil pH and Al solubility and use of laboratory indices to predict their liming effect. Soil Science, New Brunswick, v. 171, n. 10, p. 754-763, 2006.

NELSON, S. D. et al. Facilitated transport of napropamide by dissolved organic matter in sewage sludge amended soil. Journal Environmental Quality, Madison, v. 27, p. 1194$1200,1998$.

OLIVEIRA, F. C. Publicação eletrônica [mensagem pessoal]. Mensagem recebida por marchese@cena.usp.br em 26 fev. 2007.

OLIVEIRA, A. S. et al. Importância do biossólido gerado no sistema de tratamento de esgoto por lodos ativados, enfoque para a cidade de Ribeirão Preto, São Paulo, Brasil. O Mundo da Saúde, São Paulo, v. 30, n. 4, p. 634-643, 2006.

ORGANIZAÇÃO DE PLANTADORES DE CANA DO ESTADO DE SÃO PAULO. ORPLANA. Estatísticas. Piracicaba: ORPLANA. Disponível em: http://www.orplana.com.br/aspectos prod.htm. Acesso em: 14 fev. 2007.

ORGANISATION FOR ECONOMIC CO-OPERATION AND DEVELOPMENT. Leaching in soil columns. Paris: OECD, 2004. 15 p. (Guidelines for Testing of Chemicals - Guideline, $312)$. 
PARAÍBA, L. C.; LUIZ, A. J. B; PÉREZ, D. V. Estimativa da superfície específica de solos e do coeficiente de sorção de pesticidas. Jaguariúna: Embrapa Meio Ambiente, 2005. (Boletim de Pesquisa e Desenvolvimento, 29).

PARSONS, B.; WITT, J. M. Pesticides in groundwater in the USA. A report of a 1988 survey of US States. Corvallis, Oregon State University Extension Service, 1989.

PEREIRA, W. E.; ROSTAD, C. E. Occurrence, distribution, and transport of herbicides and their degradation products in the lower Mississippi river and its tributaries. Environmental Science \& Technology, Easton, v. 24, p. 1400-1406, 1990.

PINTO, G. M. F.; JARDIM, I. C. S. F. Análise fatorial para otimização de parâmetros de adsorção de herbicidas em solos, determinada utilizando CLAE. São Paulo: SBQ, 2004. Disponível em: http://www.sbq.org.br/ranteriores/23/resumos/0482/. Acesso em: 16 ago. 2004.

POLATI, S. et al. Sorption of Pesticides on Kaolinite and Montmorillonite as a Function of Hydrophilicity. Journal of Environmental Science and Health Part B, New York, v. 41, p. 333-344, 2006.

PRATA, F. et al. Degradação e sorção de ametrina em dois solos com aplicação de vinhaça. Pesquisa Agropecuária Brasileira, Brasília, v. 36, n. 7, p. 975-981, 2001.

QUEIROZ, M. E. C.; LANÇAS, F. M. HRGC Study of sortpion and desorption of atrazine, ametryn and metolachlor on Brazilian soils. Journal of Brazilian Chemical Society, São Paulo, v. 8, n. 1, p. 1-6, 1997.

RAIJ, B, van; QUAGGIO, J.A. Métodos de análise de solos para fins de fertilidade. Campinas: IAC, 1983. 31 p. (Boletim Técnico, 81).

REGITANO, J. B. Propriedades físico-químicas dos defensivos e seu destino no ambiente. In: SIMPÓSIO SOBRE DINÂMICA DE DEFENSIVOS AGRÍCOLAS NO SOLO, 2002, Piracicaba. Anais... Piracicaba: ESALQ-USP, 2002. p. 40-53.

REGITANO, J. B. et al. Imazaquin Sorption in Highly Weathered Tropical Soils. Journal of Environmental Quality, Madison, v. 29, p. 894-900, 2000.

REGITANO, J. B. et al. Sorção-dessorção do fungicida clorotalonil em solos com diferentes teores de matéria orgânica. Revista Brasileira de Ciência do Solo, Viçosa, v. 26, n. 1, p. 267-274, 2002.

ROBERTS T. R. et al. Metabolic pathways of agrochemicals. Part1: Herbicides and plant growth regulators. London: The Royal Society of Chemistry, 1998. 849 p.

RODELlA, A. A. Métodos de avaliação de materiais orgânicos e efeitos de sua incorporação ao solo sobre a mobilização de macronutrientes. 1996. $148 \mathrm{f}$. Tese (Livre Docência) - Escola Superior de Agricultura "Luiz de Queiroz", Universidade de São Paulo, Piracicaba, 1996. 
SÁNCHEZ, L.; ROMERO, E.; ARÁNZAZU, P. Ability of biosolids and a cationic surfactant to modify methidathion leaching. Modelling with pescol. Chemosphere, Oxford, v. 53, n. 8, p. 843-850, 2003.

SEOL, Y.; LEE, L. S. Effect of dissolved organic matter in treated effluents on sorption of atrazine and prometryn by soils. Soil Science Society American Journal, Madison, v. 64, p. 1976-1983, 2000.

SI, Y. et al. Influence of organic amendment on the adsorption and leaching of ethametsulfuron-methyl in acidic soils in China. Geoderma, Amsterdam, v. 130, p. 66-76, 2006.

SILVA, J. E.; RESCK, D. V. S.; SHARMA, R. D. Alternativa agronômica para o biossólido: a experiência de Brasília. In: BETTIL, W.; CAMARGO, O. A. Impacto ambiental do uso agrícola do lodo de esgoto. Jaguariúna: Embrapa Meio Ambiente, 2000. p. 143-152.

SINDICATO NACIONAL DA INDÚSTRIA DE PRODUTOS PARA DEFESA AGRÍCOLA - SINDAG. Informações do Setor. Disponível em: http://www.sindag.com.br/new/upload/inforsetor/consumo_mundial.xls. Acesso em: 18 ago. 2004.

SINGH, N. Organic manure and urea effect on metolachlor transport through packed soil columns. Journal of Environmental Quality, Madison, v. 32, p. 1743-1749, 2003.

SLUSZNY, C.; GRABER, E. R.; GERSTL, Z. Sorption of s-triazine herbicides in organic matter amended soils: fresh and incubated systems. Water, Air and Soil Pollution, Berlin, v. 115 , p. $395-410,1999$.

SMITH, S.; JOHNSON, R.; PEPPERMAN, A. B. Formulation and tillage effects on atrazine and alachlor in shallow groundwater in upland corn production. Bulletin of Environmental Contamination and Toxicology, New York, v. 67, p. 113-121, 2001.

TOMITA, R. Y.; BEYRUTH, Z. Toxicologia de agrotóxicos em ambiente aquático. Biológico, Campinas, v. 64, n. 2, p. 135-142, 2002.

TSUTIYA, M. T. et al. Alternativas de disposição final de biossólidos. In: Biossólidos na agricultura. São Paulo: ABES/SP, 2002a. p. 133-180.

TSUTIYA, M.T. et al. Características de biossólidos gerados em estações de tratamento de esgotos. In: . Biossólidos na agricultura. São Paulo: ABES/SP, 2002b. p. 89-132.

UETA, J. et al. Biodegradação de herbicidas e biorremediação - microrganismos degradadores do herbicida atrazina. Herbário - Toxicologia. Disponível em: http://www.herbario.com.br/bot/toxicologia/biodegre.htm. Acesso em: 12 ago. 2004.

VANDO, J. E.; MACEDO, L. S.; TSUTIYA, M. T. I-084 - ETE Franca: uma estação que além de tratar os esgotos, produz insumos agrícolas. In: CONGRESSO INTERAMERICANO DE ENGENHARIA SANITÁRIA E AMBIENTAL, 27, 2000, Porto Alegre. Anais... Rio de Janeiro: Associação Brasileira de Engenharia Sanitária e Ambiental - ABES, 2000. 
WANNER, U.; FUHR, F.; BURAUEL, P. Influence of the amendment of corn straw on the degradation behaviour of the fungicide dithianon in soil. Environmental Pollution, London, v. 133, p. 63-70, 2005.

WEBER, J. B.; MILLER, C. T. Organic chemical movement over and through soil. In: SAWHNEY, B. L.; BROWN, K. Reactions and movement of organic chemicals in soils. Madison: ASA; CSSA; SSSA, 1989. p. 305-334. (Special Publication, 22).

WEHTJE, G.; WALKER, R. H.; SHAW, J. N. Pesticide retention by inorganic soil amendments. Weed Science, Ithaca, v. 48, p. 248-254. 2000.

WELLS, D. A.; WALDMAN, E.; BEHL, E. Groundwater monitoring studies for agrochemicals: directions and guidelines. In: LENG, M. L.; LEOVEY, E. M. K.; ZUBKOHH, P. L. Agrochemical environmental fate - State of the art. Boca Raton: CRC Press, 1995. p. 263-272.

WORRALL, F. et al. Limitations on the role of incorporated organic matter in reducing pesticide leaching. Journal of Contaminant Hydrology, Amsterdam, v. 49, p. 241-262, 2001. 